\title{
منهجيات إعادة الصياغة العمرانية للحفاظ على المناطق التراثية
}

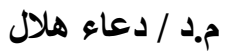 \\ مدرس بكليه هندسة المطرية \\ جامعةحلوان
}

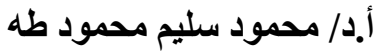

أستاذ بكليه هندسة المطرية

جامعة حلوان

\author{
م.م/ جميانة داود يوسف غطاس المباس
}

مدرس مساعد بقسم الهندسة المعمارية - كلية الهندسة بقنا جامعة جنوب فئ الوادى

Gemianadawood310@gmail.com

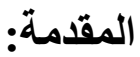

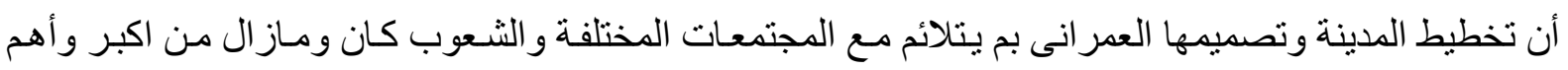

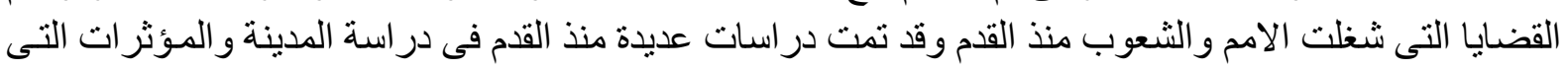

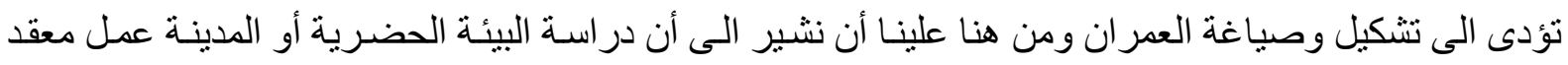

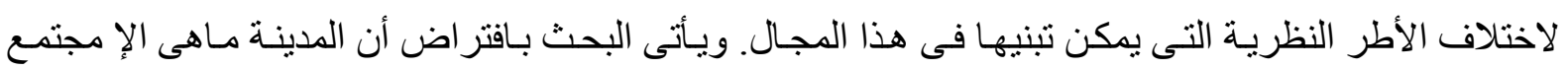

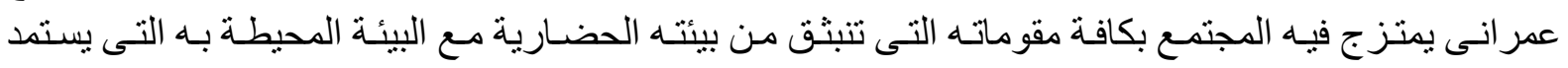

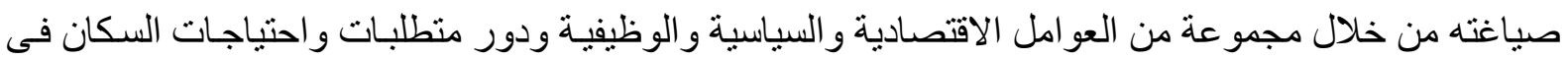
اداء هذا المجتمع.

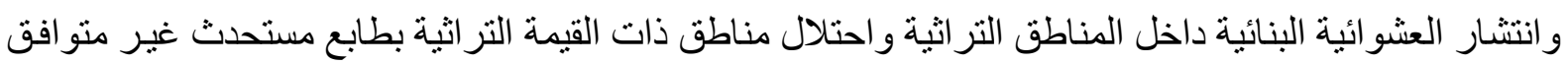

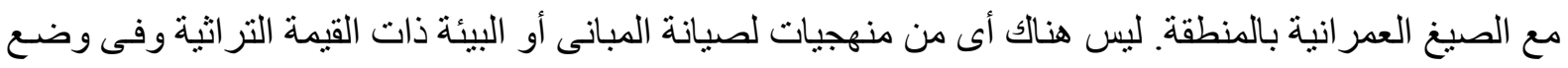

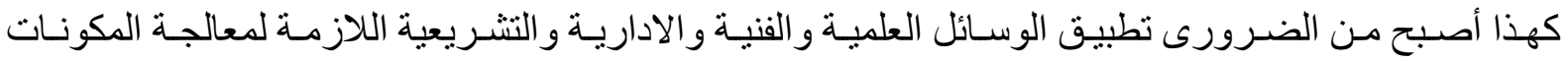

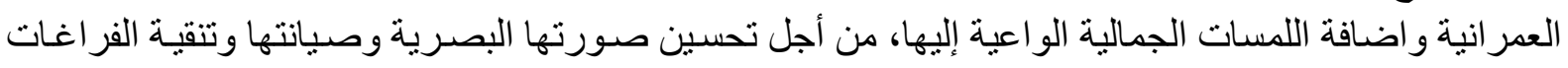
العمر انية مما لحق بها لاستعادة طابعها الجمالى.

ويتتـاول البحـث در اسـة العلاقـة بـين الصـيخ العمر انبـة المختلفـة داخـل النسـيج العمر انسى بالمجتمعـات الحضـرية و الملائمة مع المجتمعات للحفاظ على المناطق التر اثية ليساعد على وضع منهجيات الئه مقترحة يمكن تطبيقها فى أياً من المناطق التر اثية.

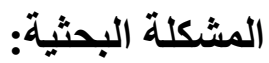

تتحدد المشكلة البحثية فى أن هذه المناطق تعانى من عدم وجود منهجية واضحة لصياغة العمر ان و الحفاظ عليه

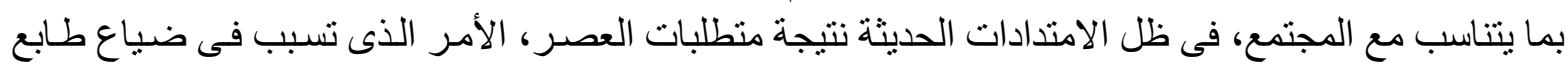
وتاريخ المدينة. 


\section{اولآ : الصيخ العمرانية والعوامل المؤثرة عليها: 1 - مفهوم الصبيغ العمرانية:}

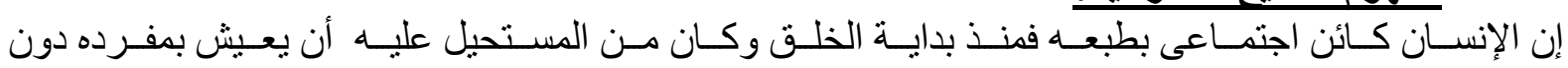

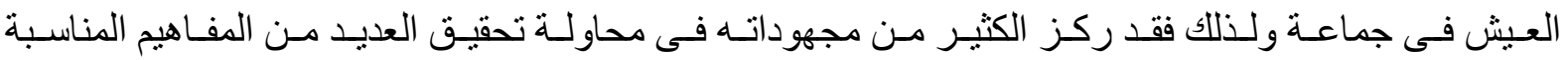

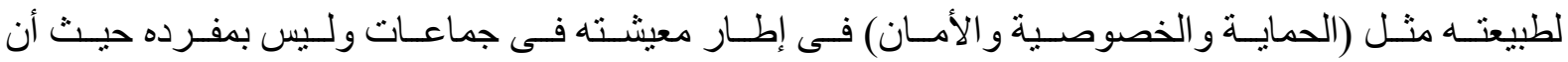
بعض هذه المتطلبات يبدو أنها تتنافى مع فكرة العيش فى جماعات.

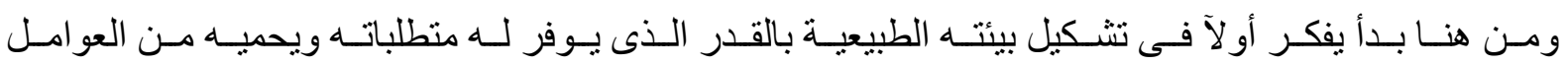

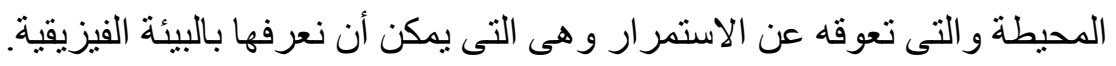

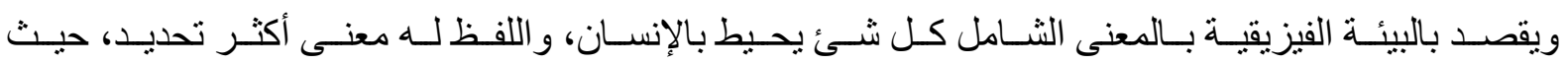
يقسم العلماء البيئة الفيزيقية إلى نمطين رئيسين:

$$
\text { بيئة طبينة بيعية. }
$$

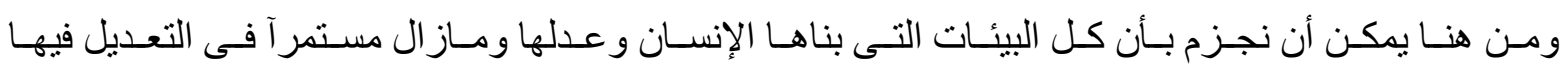

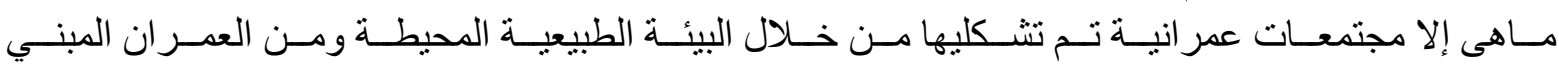

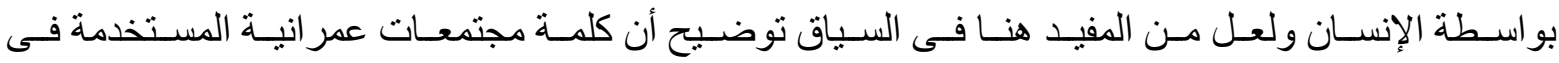

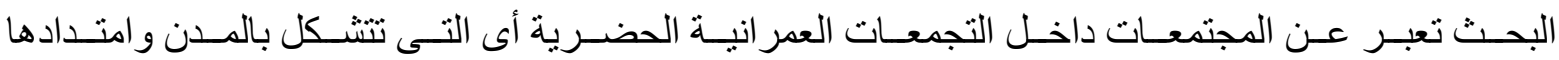
وليست بالتجمعات الريفية أو غير ها من المستوطنات البشرية (جابر ، 1991).

\section{2- العوامل المؤثرة في تحديد ملامتح الصيخ العمرانية:}

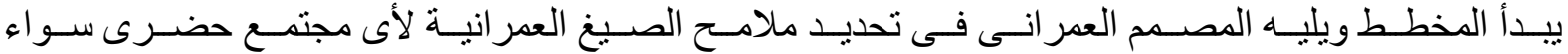

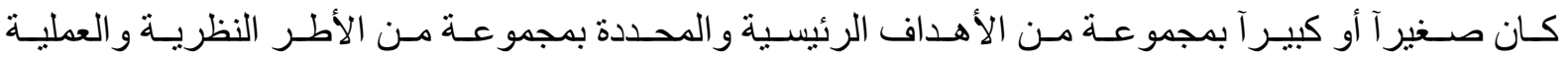

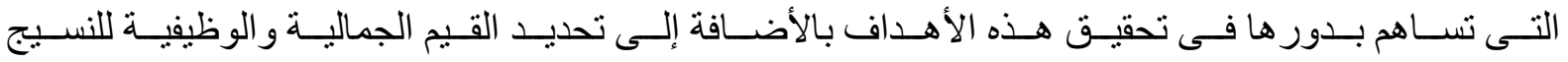

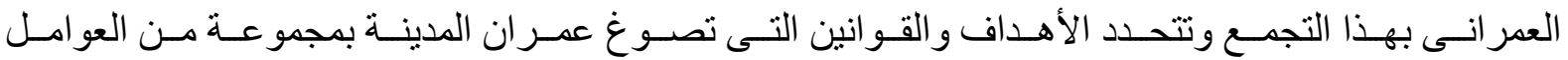

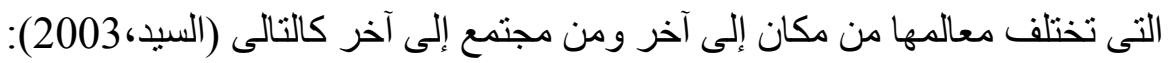
عوامل طبيعية:

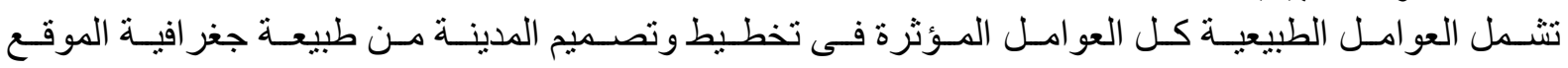
و المناخ و الكوارث الطبيعية مما يؤثر فى استر اتيجية تشكيل النسيج العمر انى.

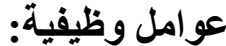

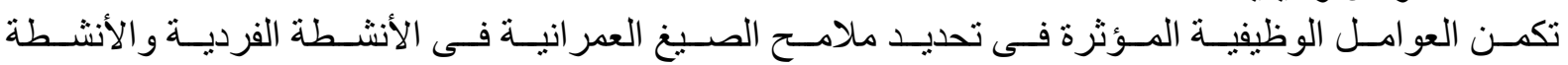

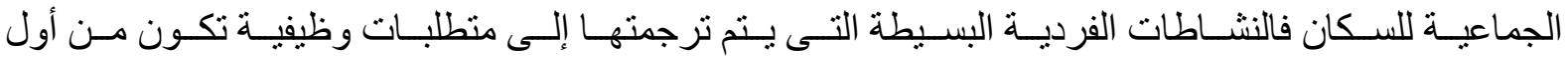

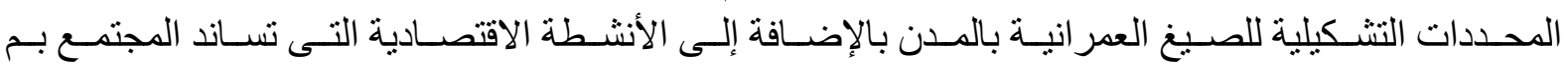
لها من منطلبات وظيفية تحقق المنفعة العامة للمجتمع ككل.

\section{عوامل سياسية:}

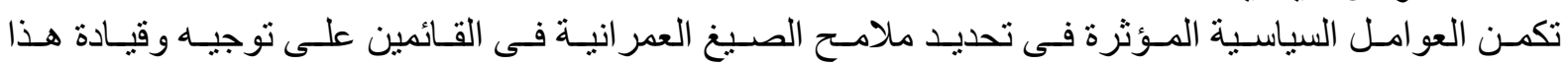

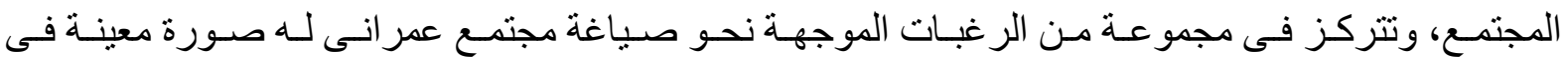

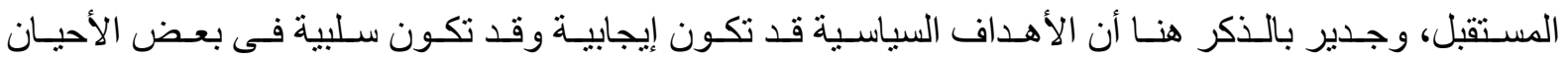
أما الأهداف الوظيفية فكلها تكون إيجابية لهذا المجتمع بعينه. 


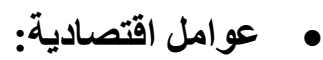

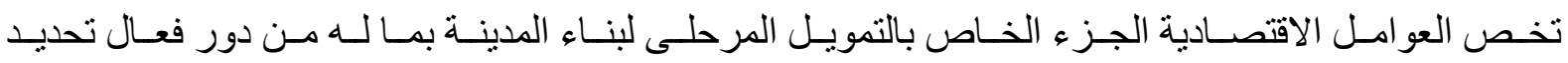

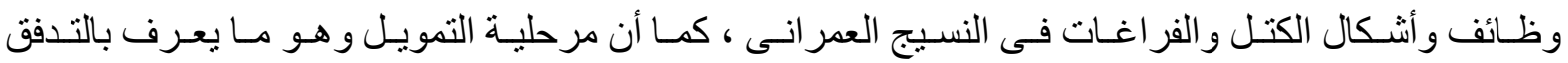

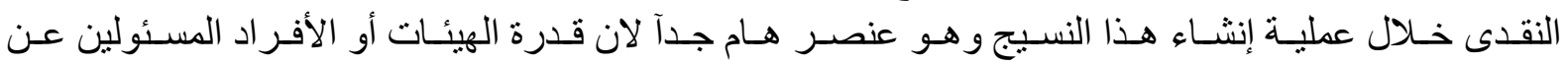

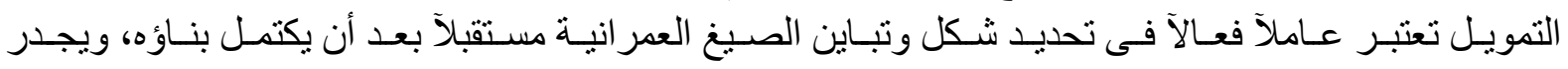

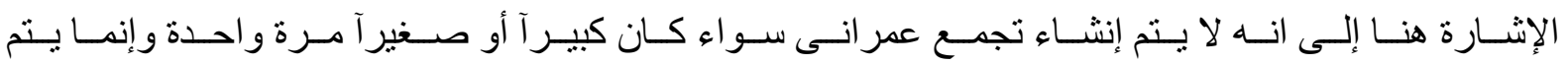

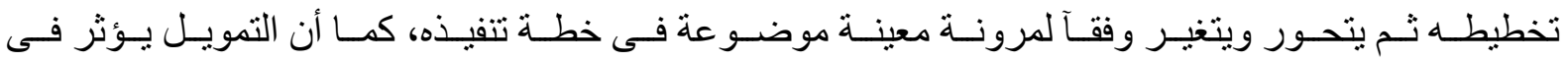

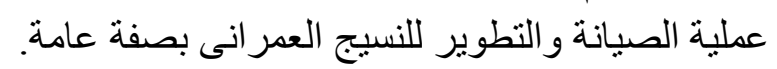

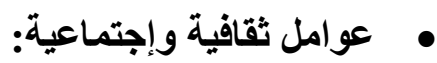

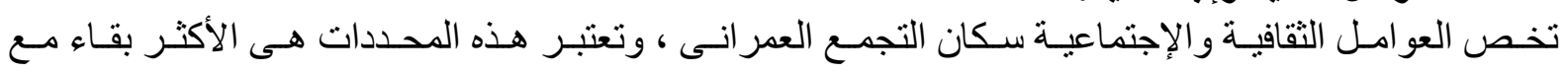

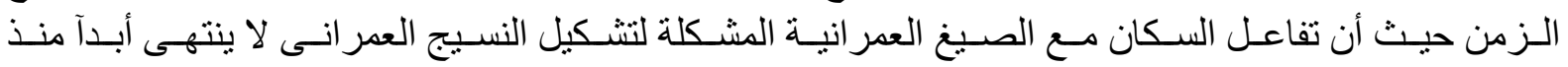

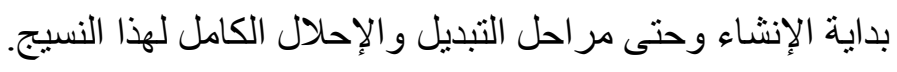

3- الانماط المختلفة للصيخ العمر انية:

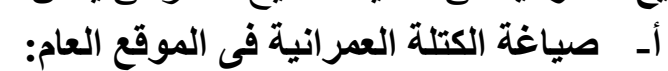

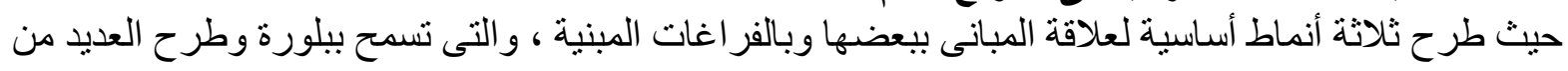
التتويعات و الأنماط و هى (نسماتة أنمات و التونى، 1977)

\section{• النمط الأول: النسيج النقطى: POINT TISSUE}

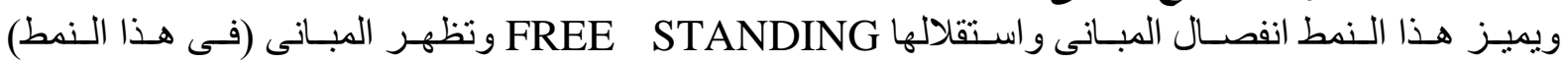
كـالجزر المنفصـلة أو الـنقط على قطاعـات أو مربعـات الأر اضـى مثـل الفيلات أو العهـار ات التـى تحيطهـا الفر اغات من جميع الجهات.

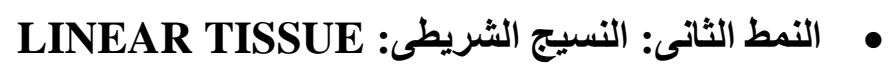

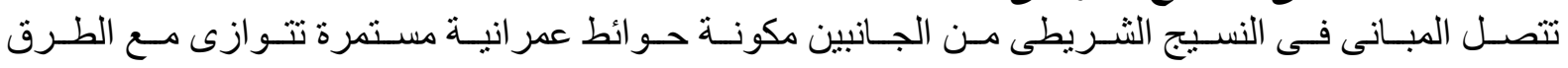
مثل المساكن المتصلة (ROW HOUSES).

• النمط الثالث: النسيج المتضام: ORTHOGNAL (COMPACT) TISSUE

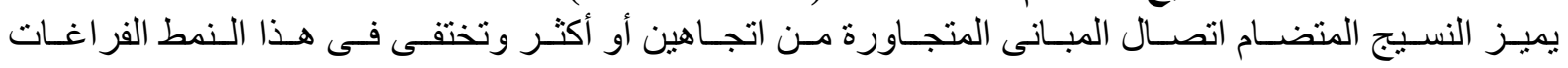

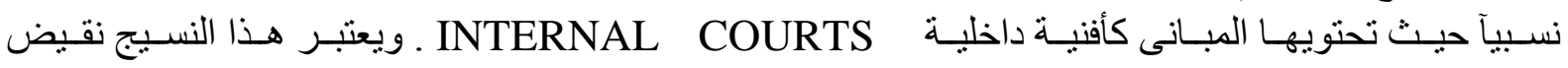
للنمط الأول.

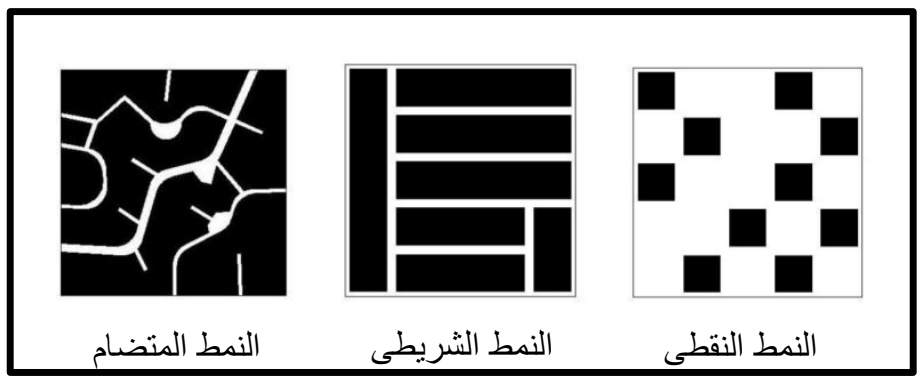

يوضح الانماط المختلفة للنسيج العمر اني المصدر: المضح الأباط 1996 Jacops" Great Streets" 


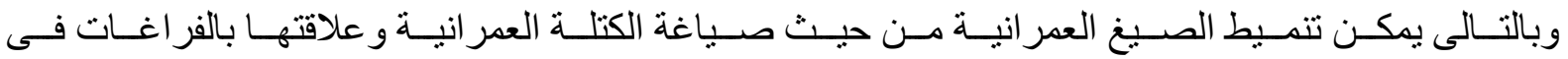

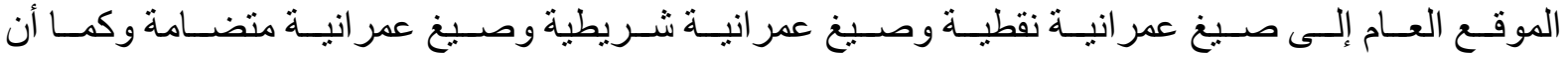

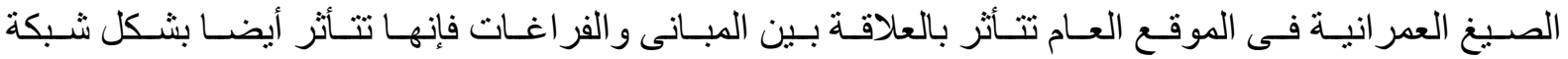

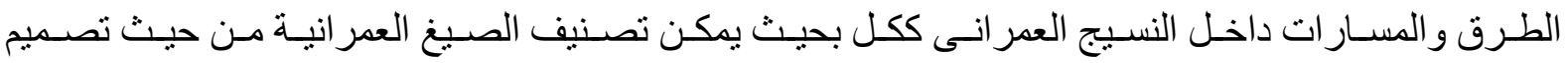
شبكة الطرق و المسار ات الى: اتى

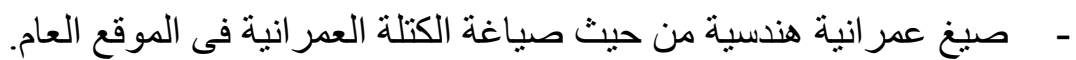
- يغ عمر انية عضوية من حيث صياغة الكتلة العمر انية فى الموقع العام.

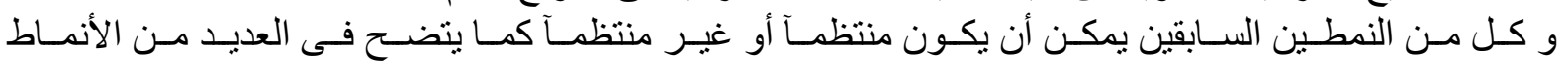
للصيغ العمر انية.
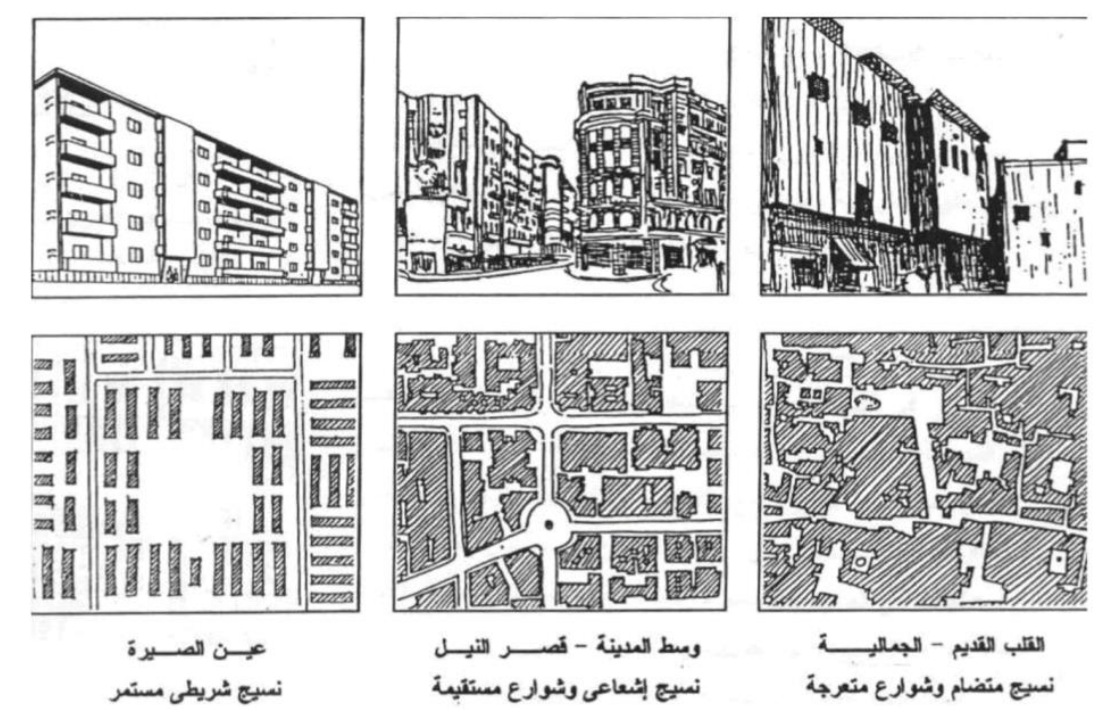

$$
\begin{aligned}
& \text { التلب التايم - الجملير } \\
& \text { نعيج متضام وشوارع متعرجة }
\end{aligned}
$$

يوضح أمثلة لأنماط مختلفة للصيخ العمر انية من حيث علاقة الكتلة بالفراغ وشبكة الطرق

المصدر: أسامة السيد أحمد،2003 العند

$$
\text { ب- صياغة الكتلة العمر انية فى البعد الثالث: }
$$

يمكن تنميط الصيغ العمر انية من حيث صياغة التهة الكتلة العمر انبة فى البعد الثالث كما يلى:

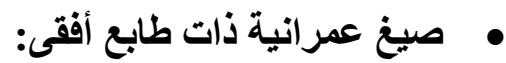

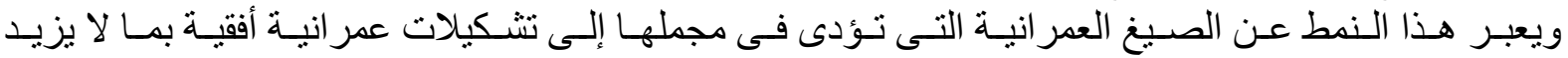

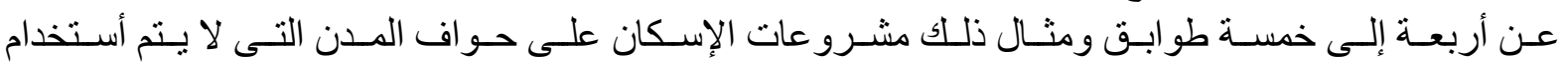
وسائل الاتصال الميكانيكية فيها WALK UP SYSTEM السعهيد، ومال 2003).

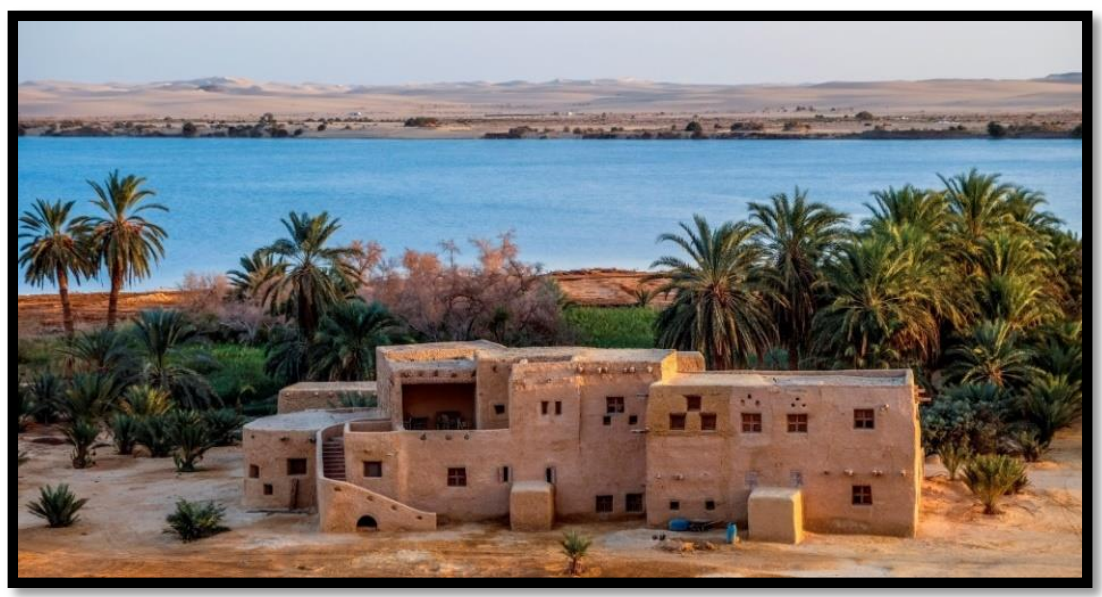

يوضح مثال للصيخ العمر انية ذات الطابع الأفقى.

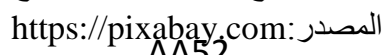



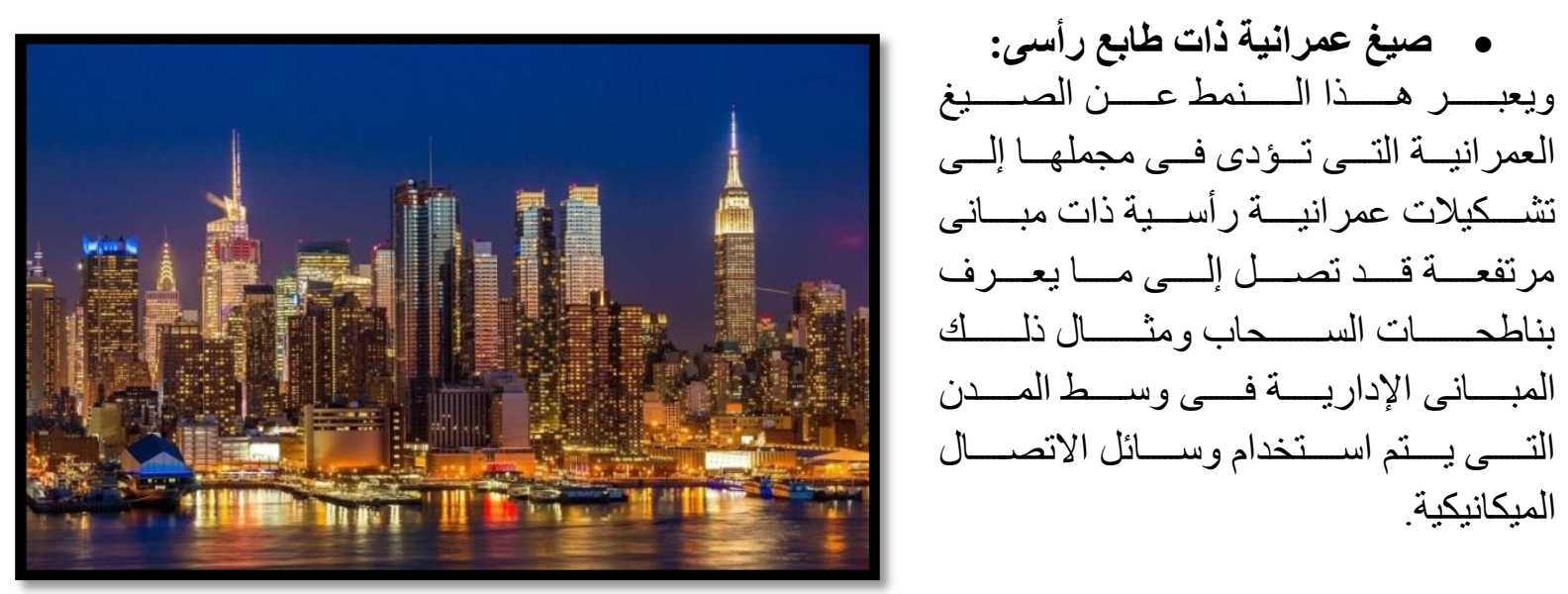

يوضح مثال للصيغ العمر انية ذات الطابع الر أسى.

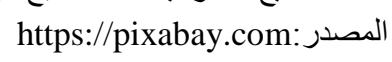

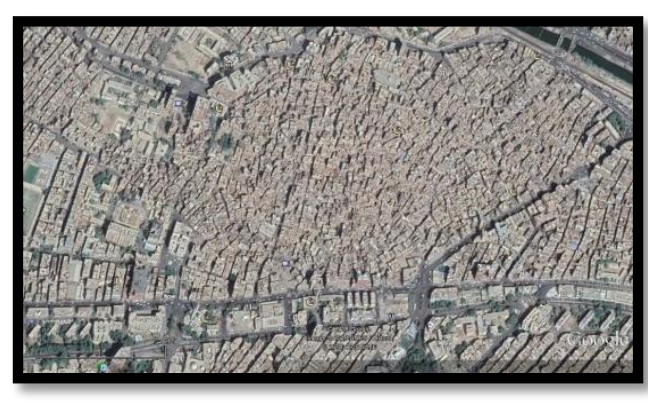

تصوير جوى - لمركز مدينة قنا يظهر فيها النسيج المتضام google earth : لمصدر مداين

\section{4- خصائص النسيج العمرانى للمناطق التراثية:}

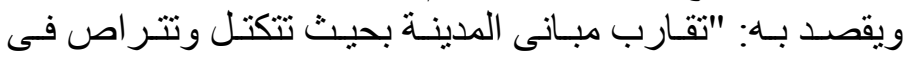

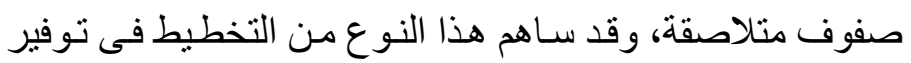

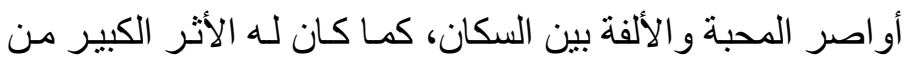

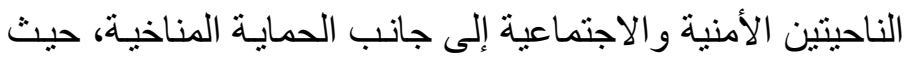

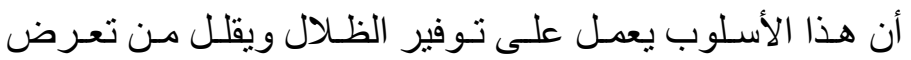

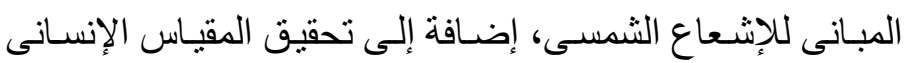

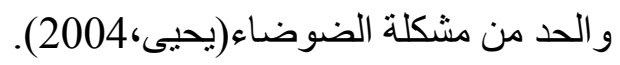
ب- الارتفاع المنحفض والكثافة العناء العالية

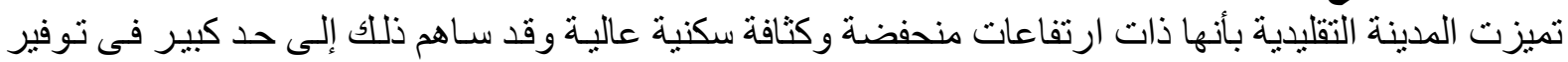

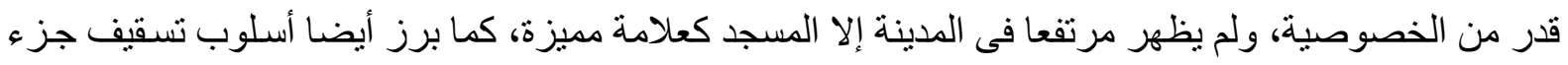

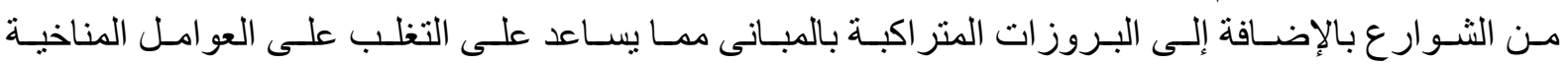

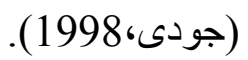

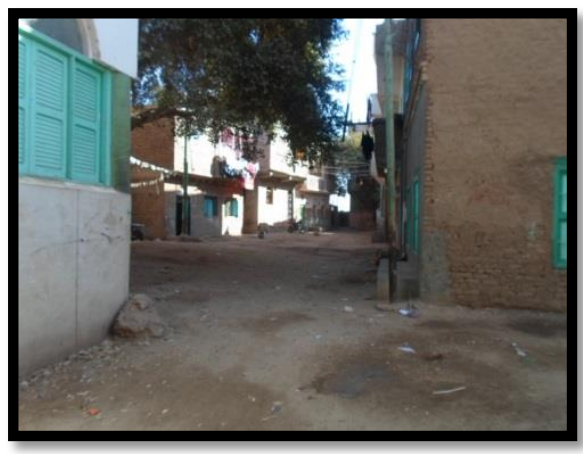

$$
\begin{gathered}
\text { يوضح الشكل التدرج الفر اغى : الباحث } \\
\text { المصدر }
\end{gathered}
$$

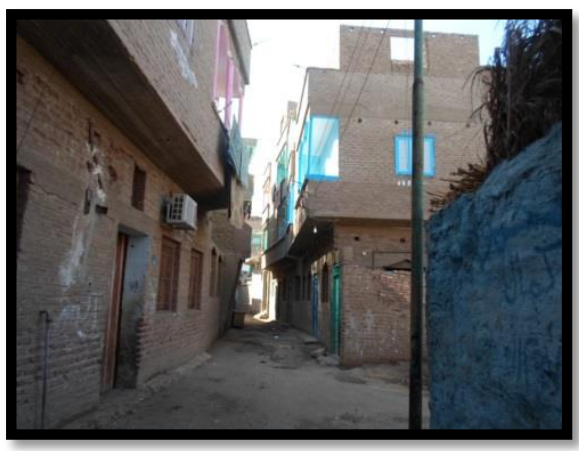

يوضح الثكل الارتفاع المنخفض و الكثافة العالية

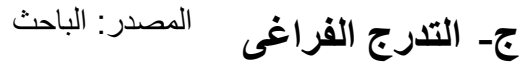

لقد ساعدت التكوينات العمر انية للمدينة التقليدية وارتباطها بشبكة الطرق على إيجاد محاور حركة ذات فر اغات متباينة فى الشكل و المقياس تبعا للأنشطة المرتبطة بها أدى إلى تكوين تدرج فر اغى منميز. 


\section{د- خصوصية طابع المكان}

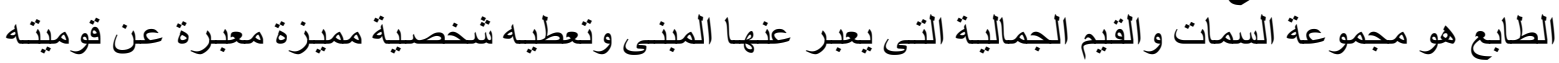

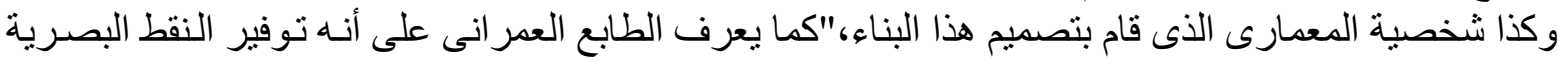

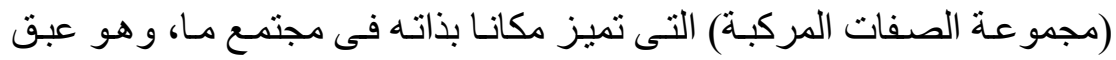

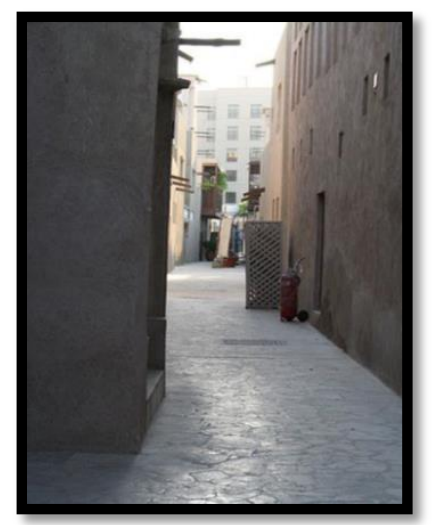

المكان.

\section{هـ - الثوارع والطرق المتعرجة والضيقة}

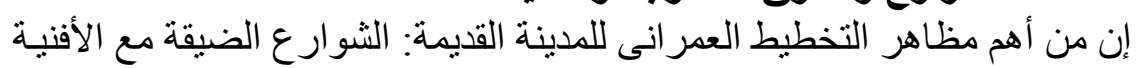

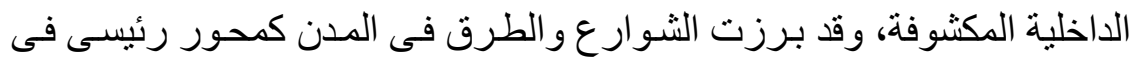

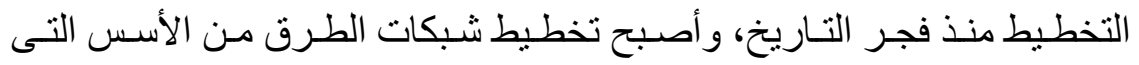

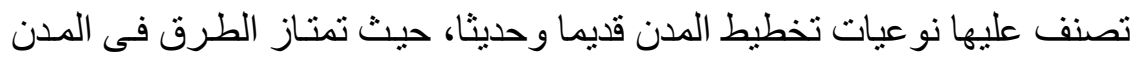

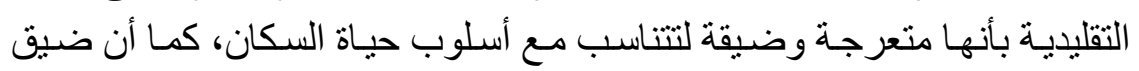
الشو ارع مع التعرجات و الانحناءات أتاح وجود مناطعة مناطق مظللة.

يوضح الثكل الثوارع الضيقة و المتعرجة فى الثى

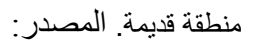

https://pixabay.com

\section{5- ملامح النسيج الحضرى للمناطق التراثية:}

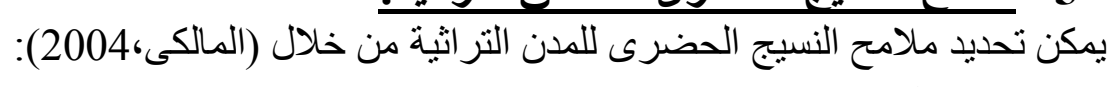

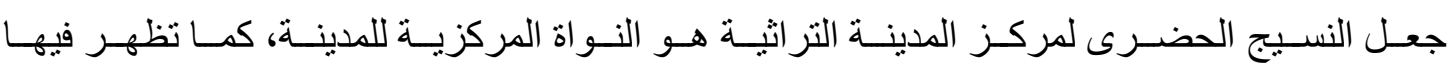

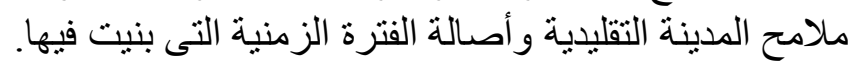

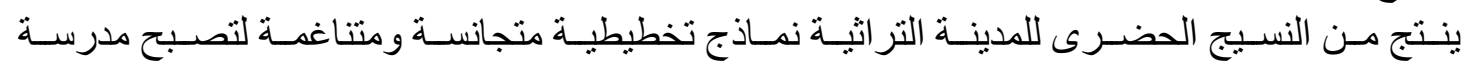
يمكن الاستفادة والاستلهام منها فى التخطيط المستقبلى و الامتداد الجديدة للمدينة.

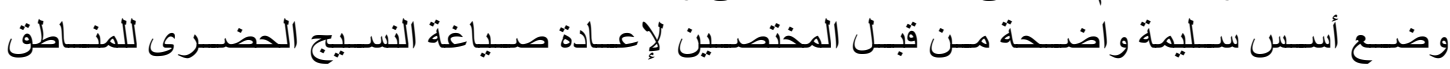

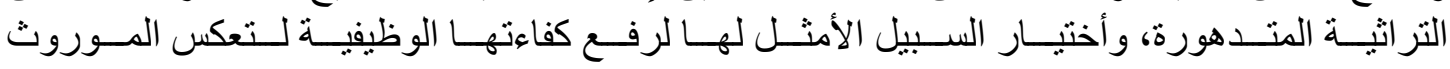
الحضارى.

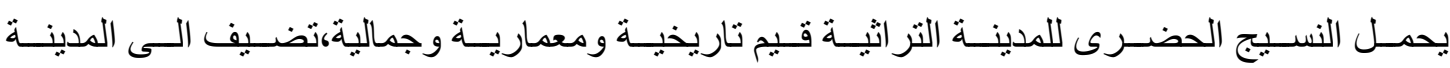

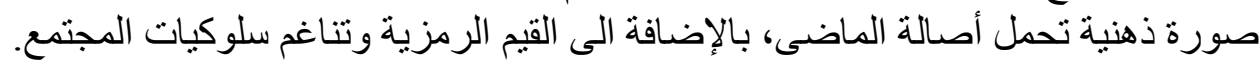

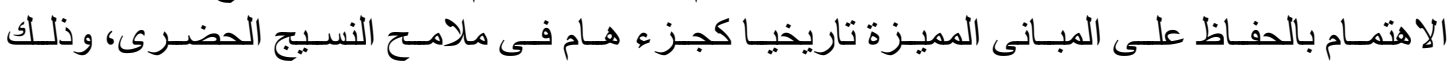
لما تحمله من هوية حقيقية لتاريخ المدينة لزيادة الفعاليات الاجتماعية والثيام الثقافية.

\section{ثانيا : الحفاظ على المناطق التراثية:

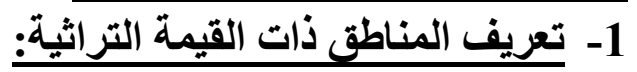

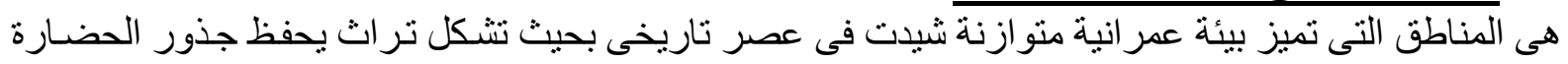

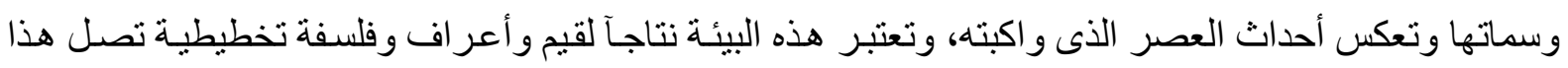

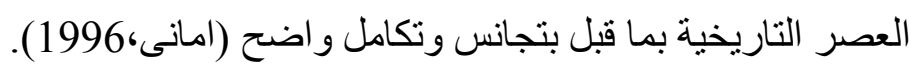

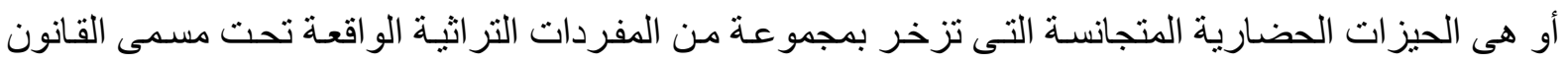

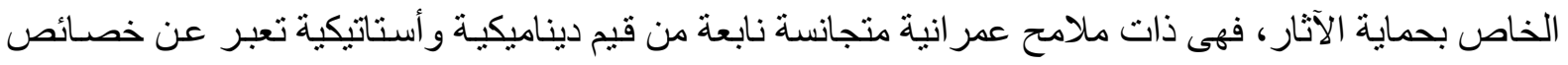

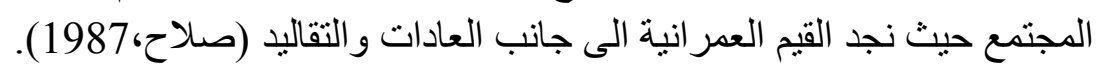

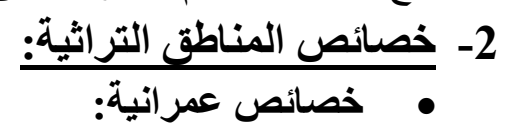
وقد تبدلت الخصائص العمر انية للمناطق التراثية وتقسمت الى: 


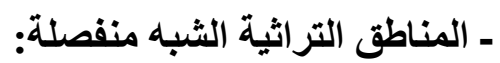

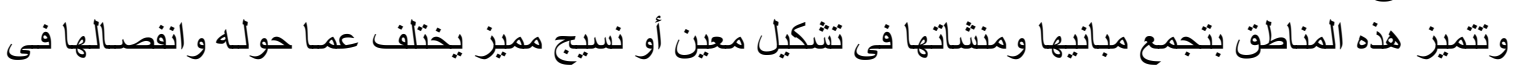

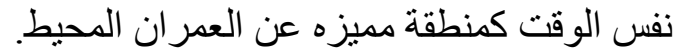

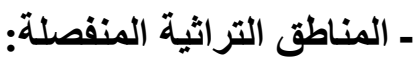
تتميز هذه المناطق بانفصالها التام عن العمران المحيط وتميز ها عن نسيجه السائد ووجودها كمجمو عات أو أو

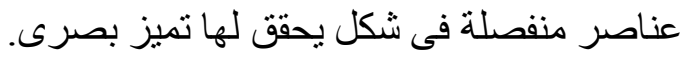
خصائص اقتصادية:

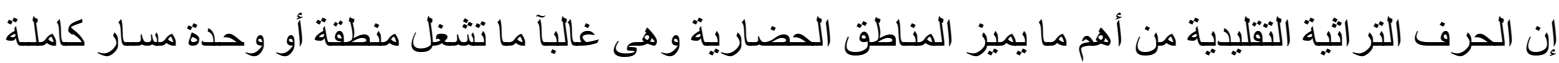

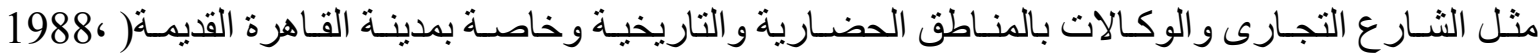
.(Azza

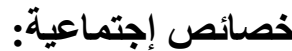

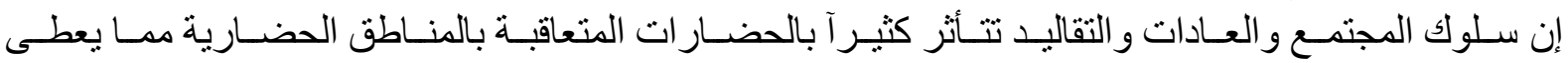

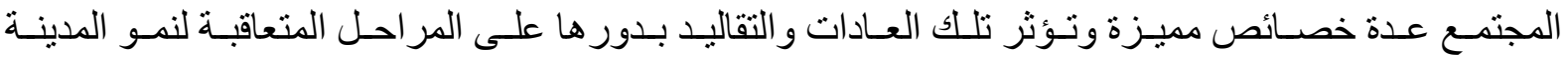

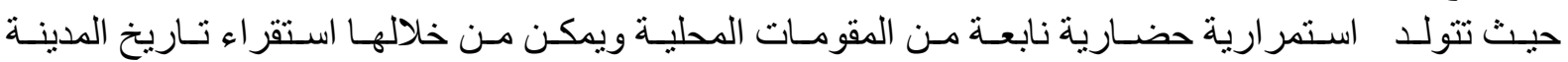
فى مراحلها المختلفة (فرنسو ا، 1988).

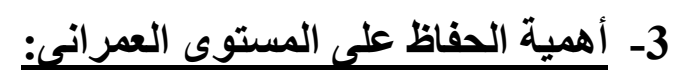

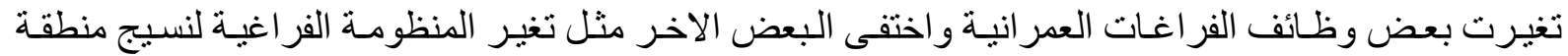

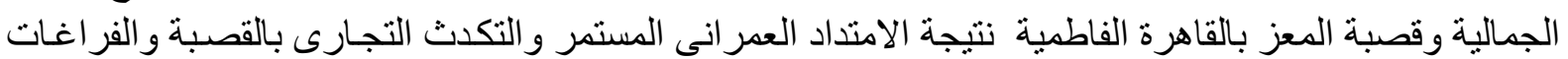

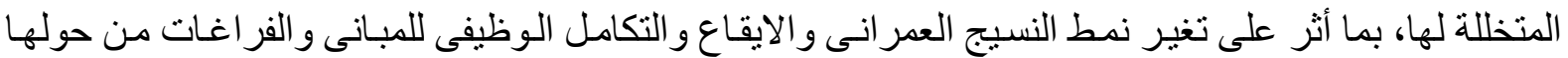

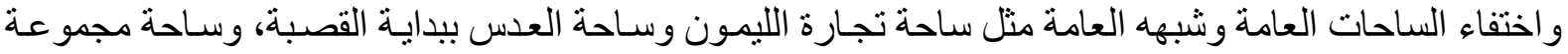

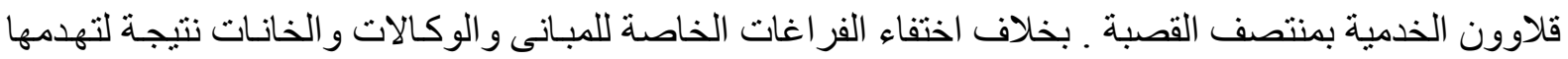

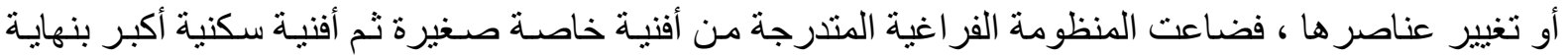

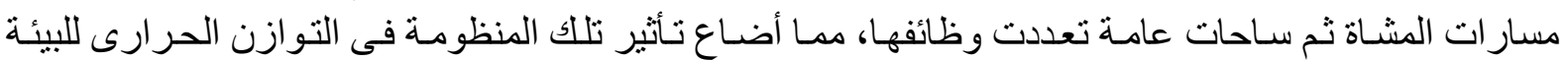

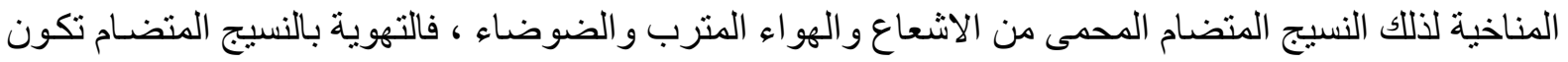

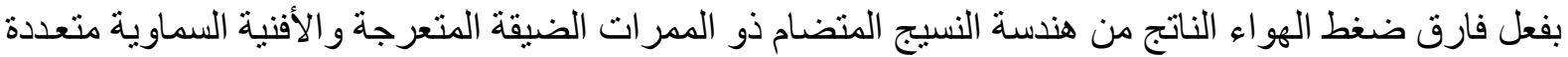

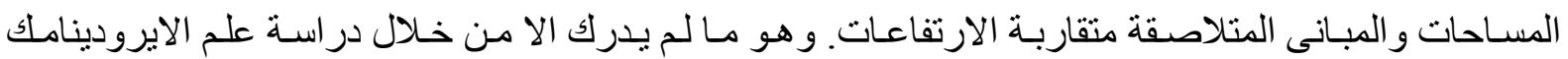

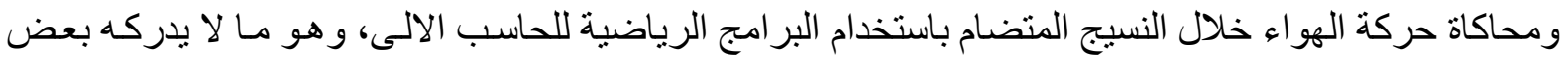

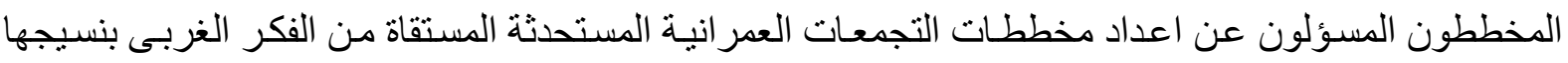

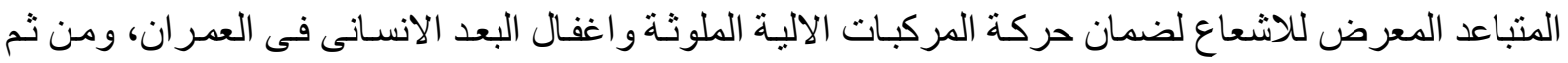

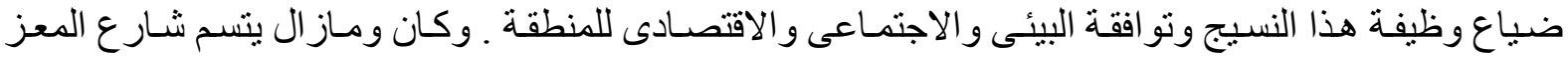

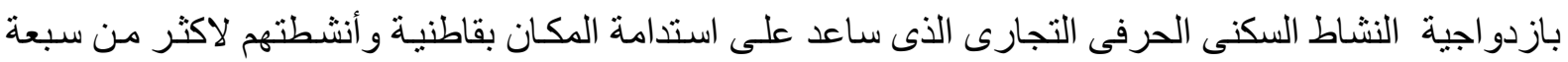

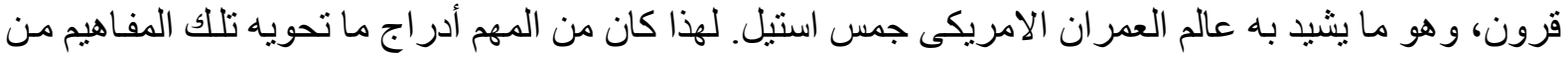
مواد معرفية وتحويلها الى معايير ومهار العرات معرفية وعملية. 

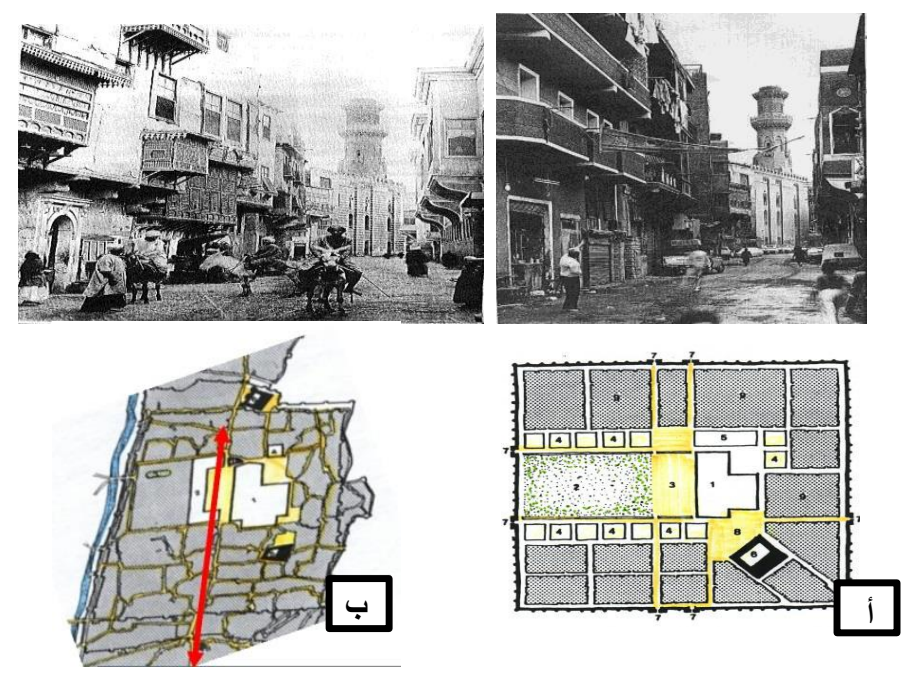

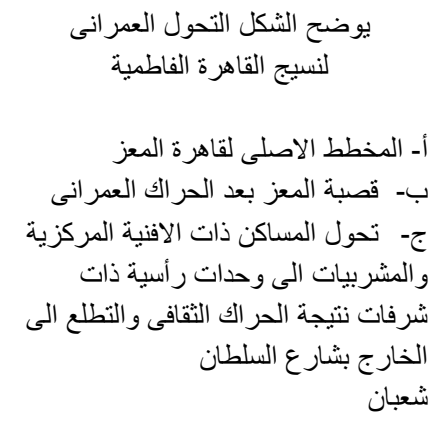

4- اسبباب تدهور المناطق ذات القيمة التراثية:

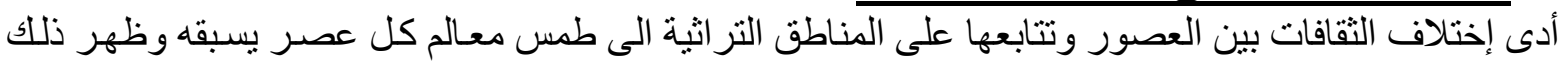

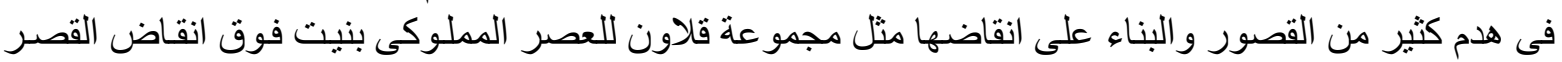

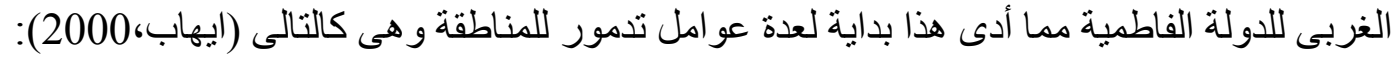

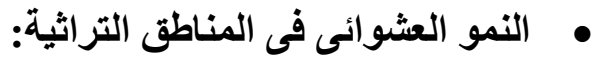

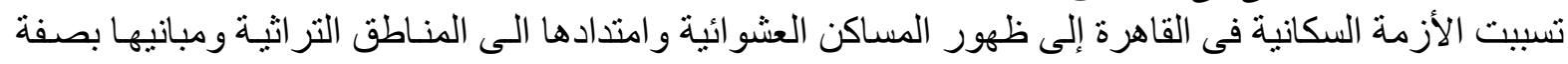

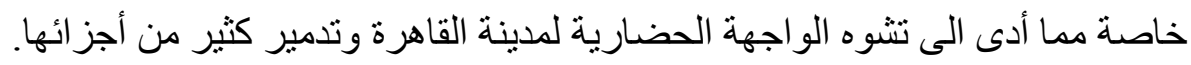

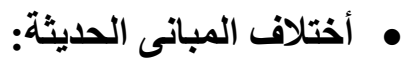

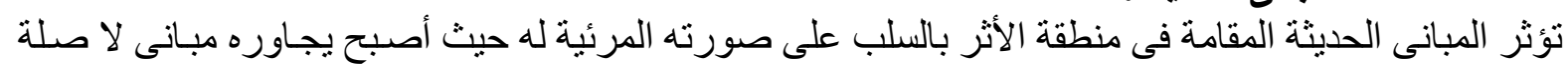

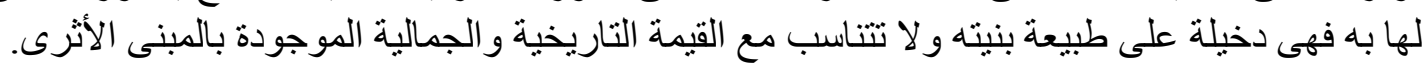
انتشار الملوثات البيئية:

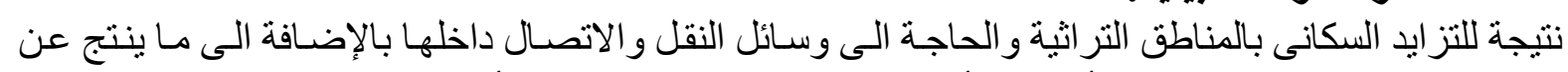

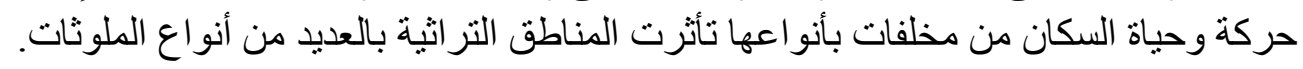

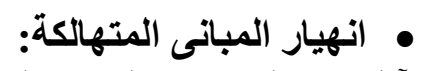

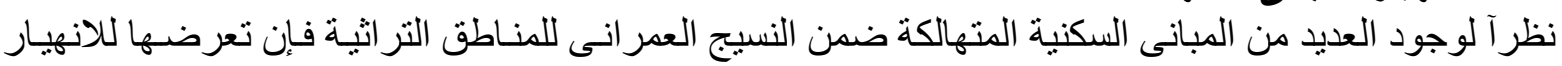
بفعل التقادم أو بفعل العو امل الطبيعية.

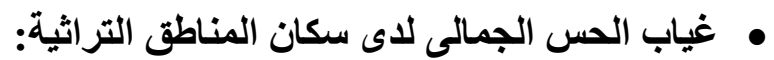

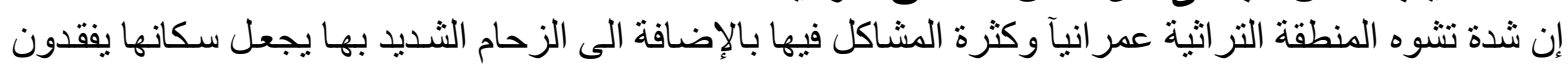

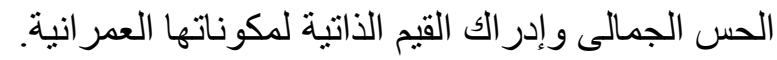

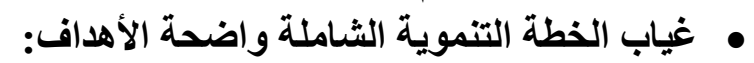

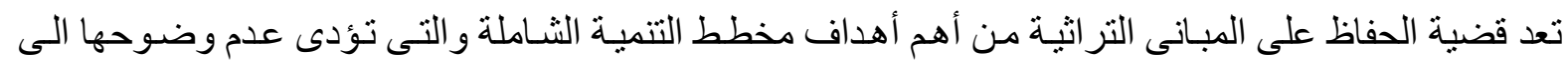

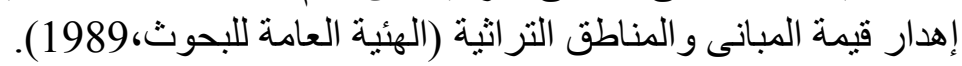

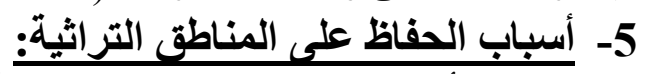

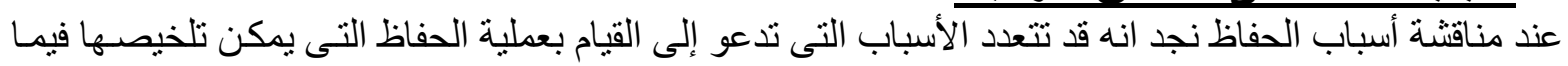
يلى: أسباب إجتماعية وتاريخية: و هى الحاجة إلى استمر ار الوظيفة الإجتمارية: إجناعية وربطها بذكريات شاغلى المبنى أو المنطقة القديمة التى تعد تجسيدآ لأحداث وفترات تاريخية وشخصيات لها تأثثير على الأحداث. 
تعد الوظيفة السياحية للتر اثلة العمر انى مصدر مهما للاخل مع أمكانية أعادة استخدام المنـاطق و المبانى المحافظ عليها سو اء كمزار ات أو متاحف ثقافئة

\section{•}

يتم من خلال الحفاظ على المبانى ذات القيمة التاريخية التعلم من الماضى وسرد التاريخ بأحداثه العظيمـة و التعبير

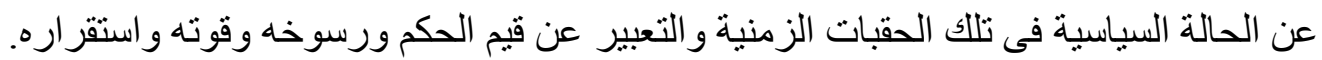

\section{• أسباب دينية وعقائدية:}

يتم من خلال عملية الحفاظ و التعبير عن المكانة الكبيرة لدور العبادة و المبانى الدينية.

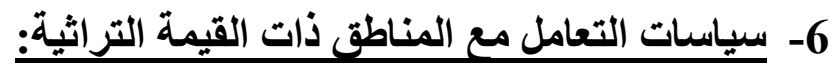

تتتوع الأساليب التى يتم بها التعامل مع المبانى و المناطق التر اثية، وينم تحديد أسلوب التعامل مع كل منطقة بمـا

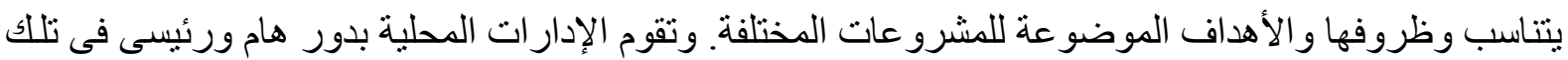

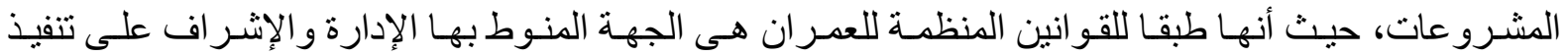

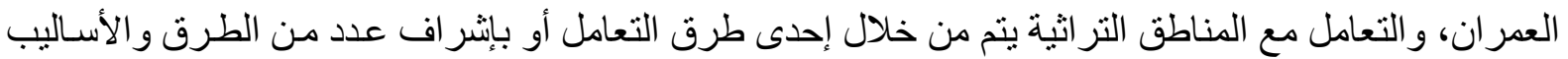

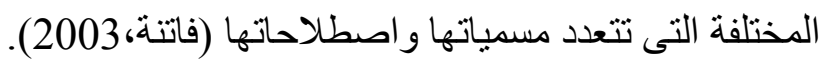

سياسات التعامل مع المبانى التراثية.

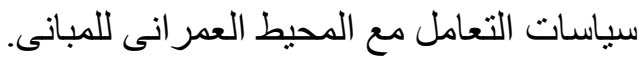

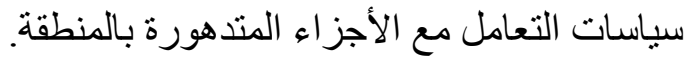
السياسات الثاملة للتعامل مع المناطق.

\section{7- تأهيل المراكز في المناطق التراثية:}

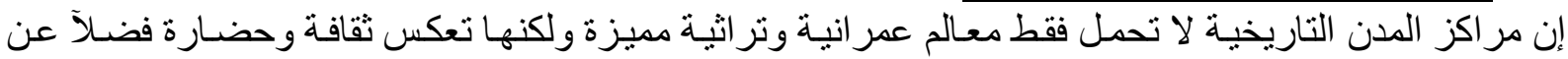

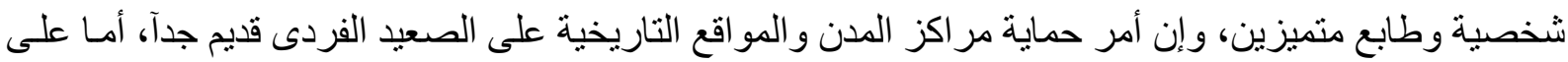

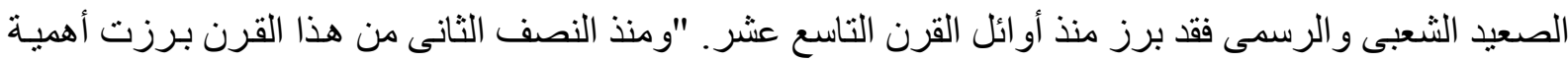

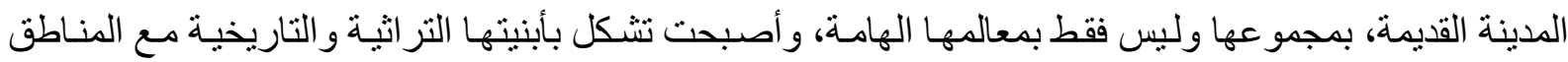

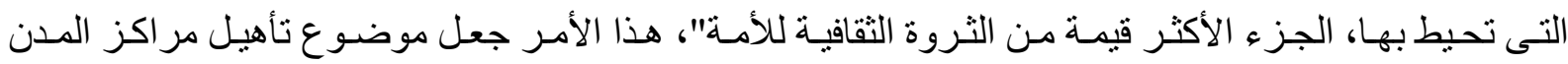

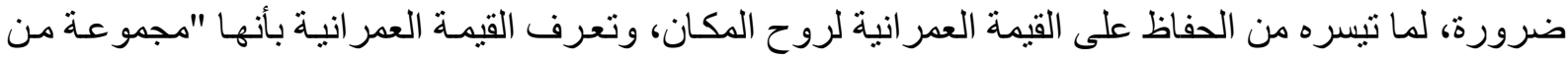

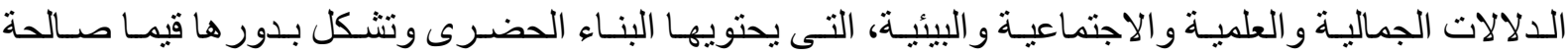

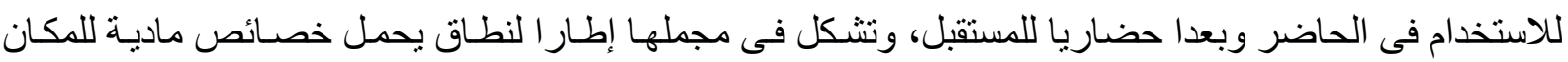

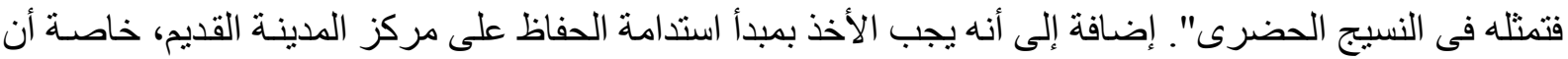

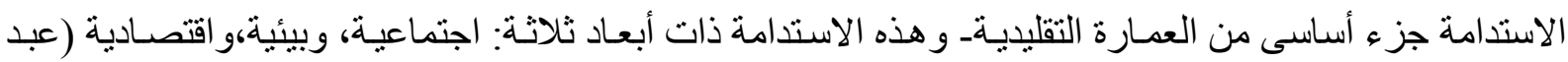

ثالثاً : العلاقة التبادلية بين العمران والحفاظ على الهوية والتراث الثقافى:

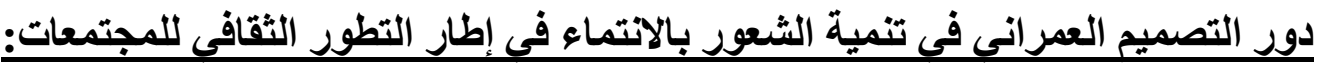

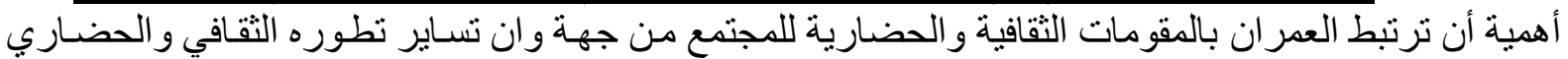

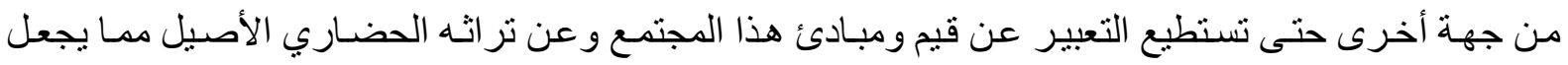

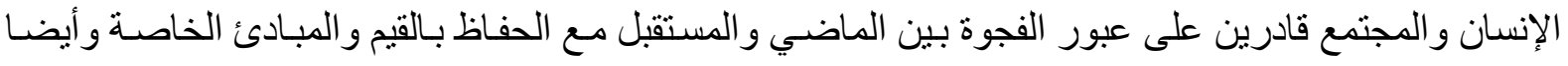


على التكيف وتقبل التطور و التقدم ممـا ينعكس إيجابـا على المجتمع و على صحة الإنسـان النفسية و على شـعوره

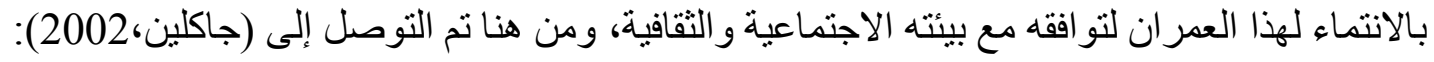

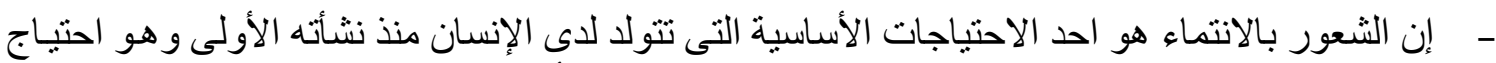

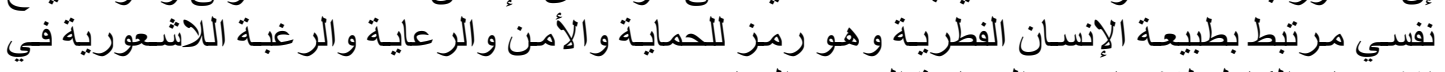
الانسحاق الكامل للإنسان في الجماعة المنتمى إليها. يعبر عن الانتماء بسلوك يقوم به الإنسان تجاه بيئته المحيطة وهذاعة الإنها لا يتم إلا بعد أن يتفاعل الإنسـان مع

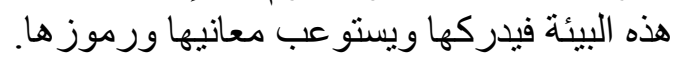

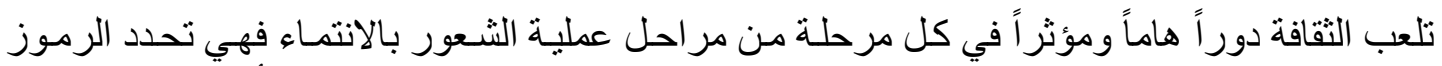

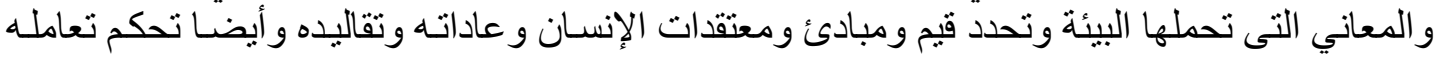

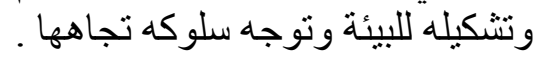

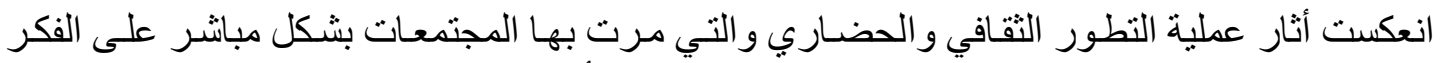

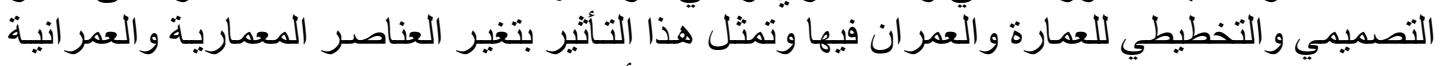

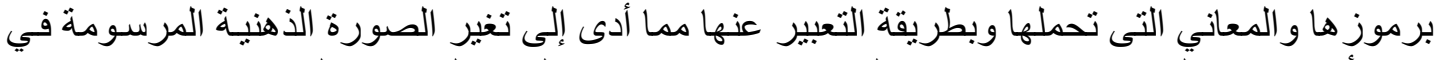

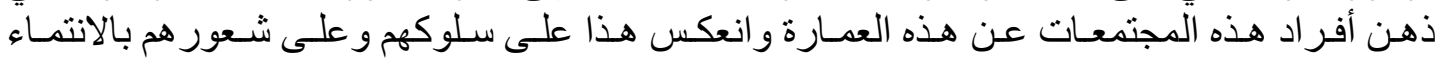

\section{رابعآ: النتائج:}

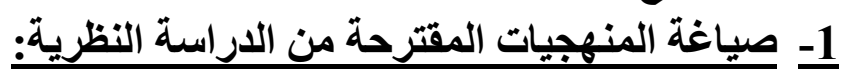

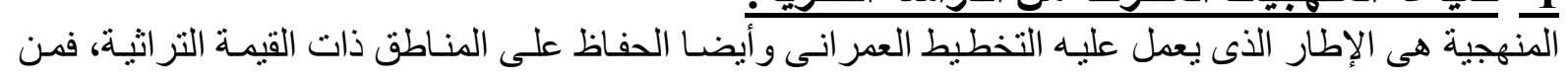

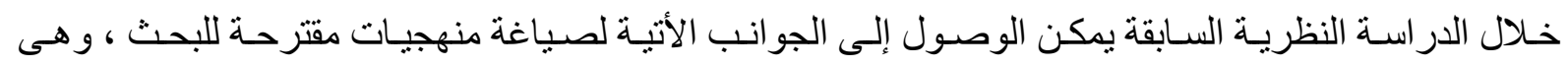
تحتوى على عدة جوانب هامة لهذه الصياغة كالتالى:

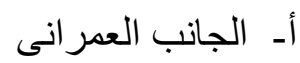

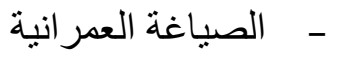

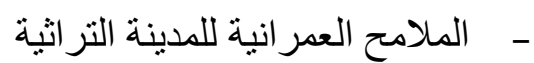

$$
\begin{aligned}
& \text { ب-منهجيات الحفاظ على المناطق ذات القيمة التر اثية } \\
& \text { ت-منهجيات التعامل مع المناطق ذات القيات القيمة التراثية التية الثية }
\end{aligned}
$$

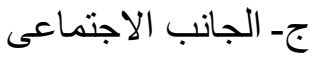

$$
\begin{aligned}
& \text { د- منهجية إعداد بر امج ومشاريع }
\end{aligned}
$$

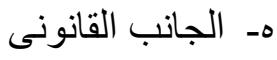

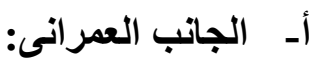

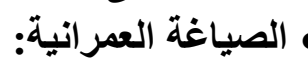

لالكتنة: در اسة المخططات التفصيلية للكتلة العمر انية وتحديد النمط العمر انسى المميز لهاودر اسـة العلاقة

$$
\text { بين المبانى وشبكة الطرق وربطة والطهم بأسلوب مميز. }
$$

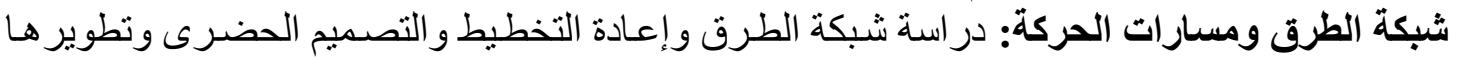

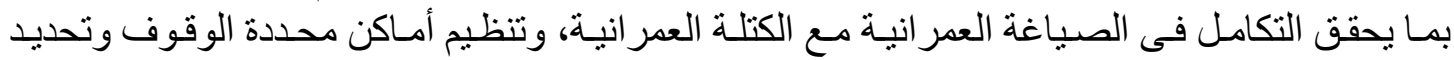
مو اقف سيار ات.

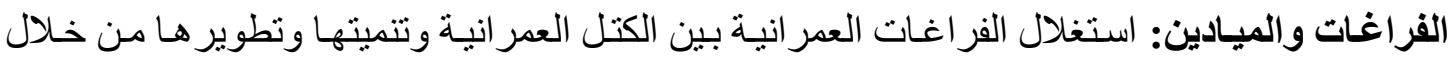

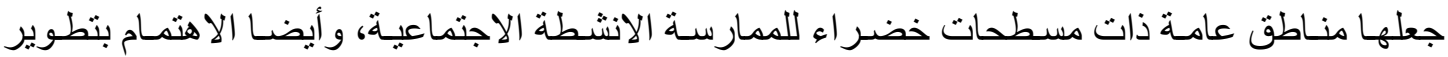

الميادين كعلامة مميزة بالمناطق العمر انية. 


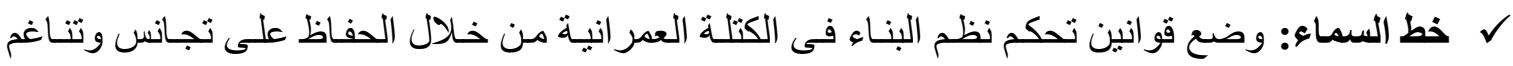

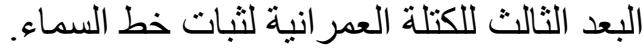

\section{• • الملامح العمرانية للمدينة التراثية}

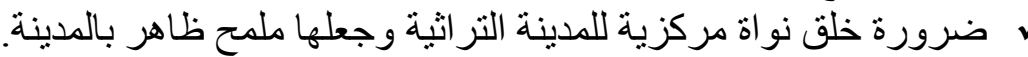

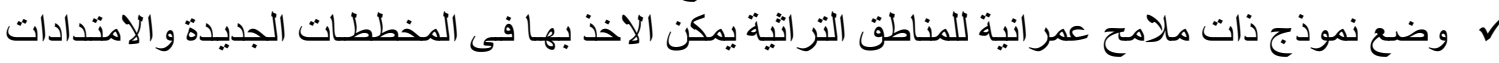
الحديثة. ل وضع أسس وقو انين حازمة من قبل المختصين لاستخدامها فى إعادة صياغة النسيج الحضرى للمنـاطق

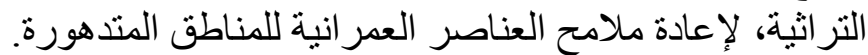

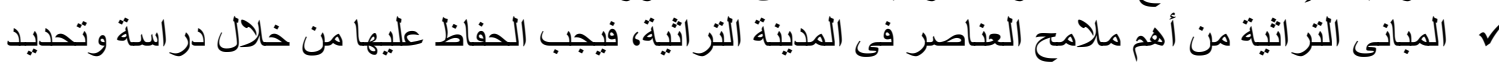

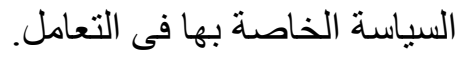

\section{ب - منهجية الحفاظ على المناطق ذات القيمة التراثية:}

\section{الإجراءات التى يجب اتخاذها فى الحفاظ على المناطق التراثية:}

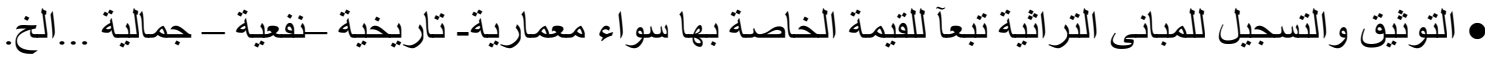

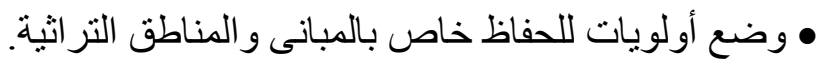
• وضع قو انين منعلقة بسير الإجر اءات المتأخذة فى الحفاظ وتفعيل تطبيقها بشكل كامل.

> وسائل الحفاظ على المناطق التراثية:

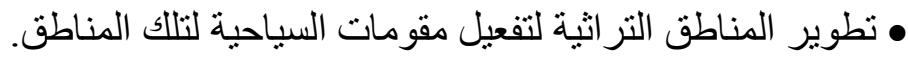

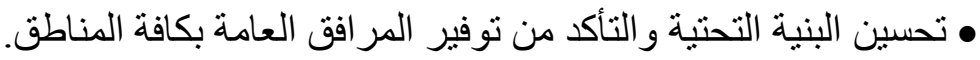

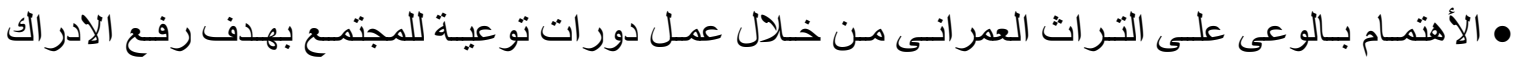

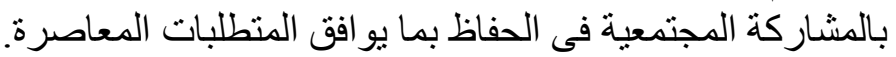

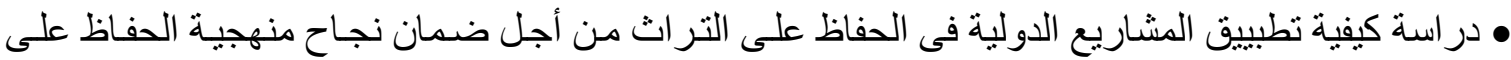
المناطق التر اثية.

\section{ت ـ منهجية التعامل مع المناطق ذات القيمة التراثية: > منهجية التعامل مع المناطق التراثية:}

هناك سياسات كثيرة تم ذكر ها فى الدر اسة النظرية يتم من خلالها التعامل مع المحيط العمر انى سو اء على مستوى

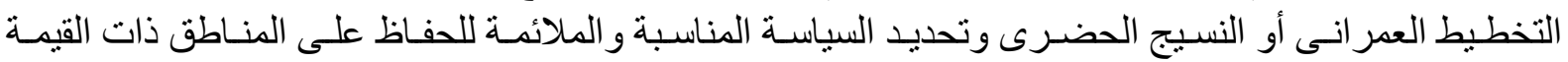

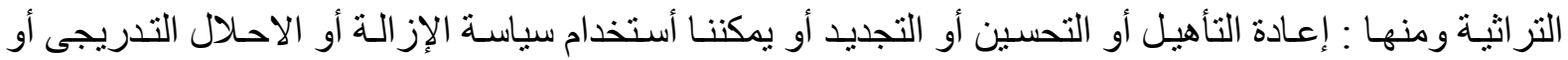
إعادة التعمير، للمناطق التر اثية المتدهورة.

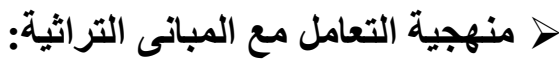

يمكن استخدام سياسة الحفاظ و الإحياء و غير هما من سياسات يمكن التعامل معهم دون المسـاس بـالطر از و الجو هر بالتر اث الموجود بالمبانى، و أيضـا يمكن من خـلال الإحباء بالمبانى يمكن إعـادة توظيف و واستعمال المبنى مرة أخرى لأغر اض مشابهة.

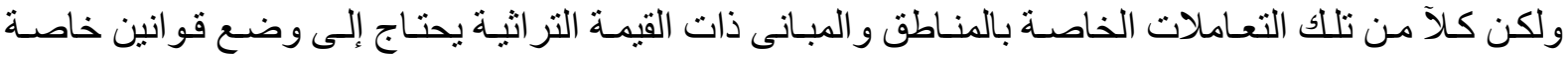
بالحفاظ بحيث يجب تطبيقها وفقاً لطبيعة كل سياسة للحفاظ على الموروث العمر انى و المعمارى. 


\section{ج - الجانب الإجتماعى:}

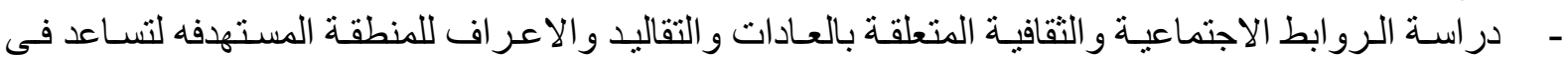

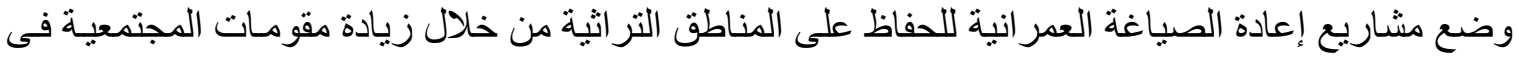

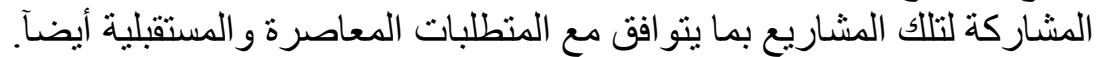

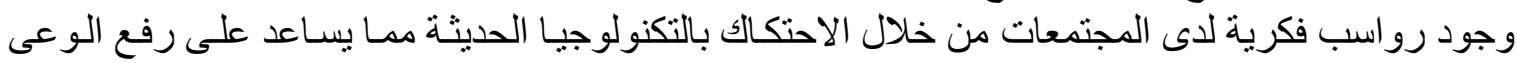

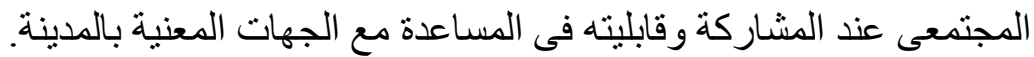

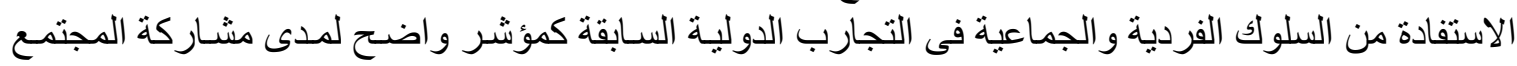
فى إعادة الصياغة العمر انية لعمليات الحفاظ. عمل بـر امج توعيـة للمجتمع من الناحيـة الاجتماعية و الثقافيـة حتى يكون هنـالك تعامل إيجـابى مـع مشـاريع الحفاظ و إعادة الصياغة. مشاركة أفر اد المجتمع فى وضع القياغة النين الخاصة بالحفاظ مما يعطى الاحساس بالانتماء الثديد بالمنطقة التى يعيشون فيها. دـ منهجية إعداد برامج ومشاريع تتضمن العلاقة بين التراث العمرانى والجانب الاجتماعى:

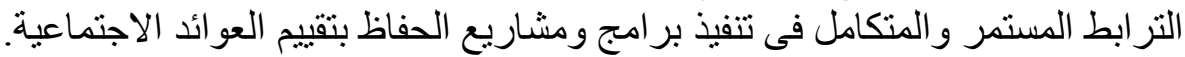

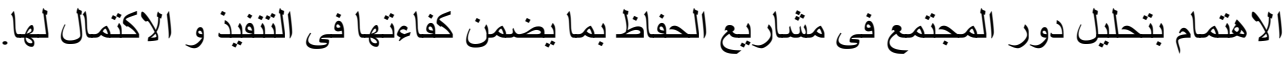
تحقق المنهجية زيادة تفاعل متخذى القرار ويحقق استمر ارية و اكتمال هذا المشروع.

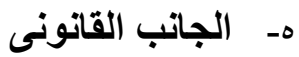

وضع قانون خاص بالمؤسسات المعنية بالمدينـة ينظم العلاقة بين إعـادة الصياغة العمر انيـة والجفاظ وكيفيـة

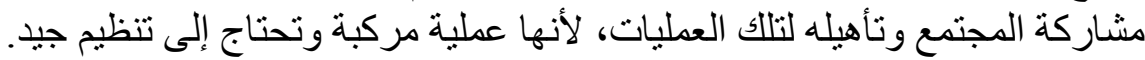

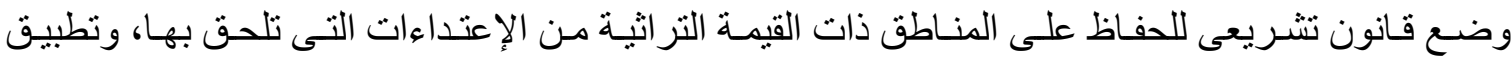

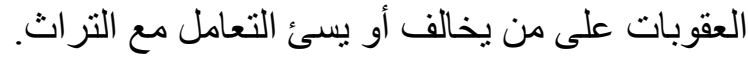

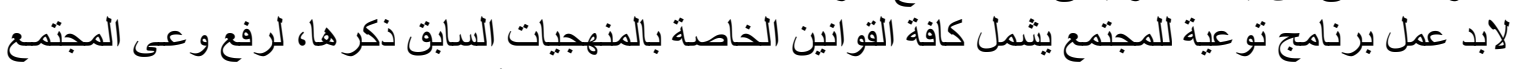

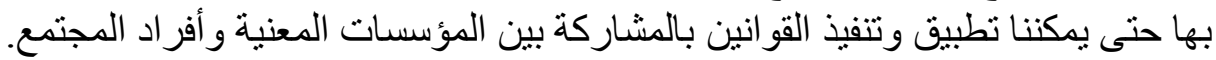

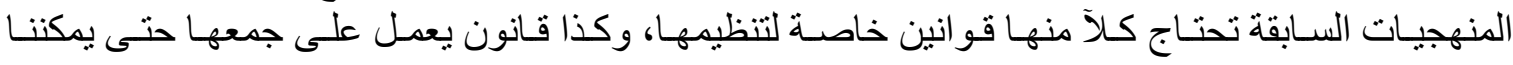

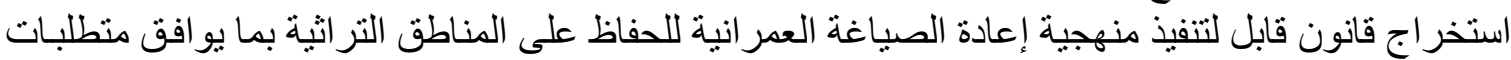

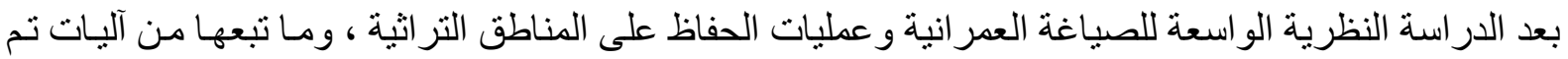

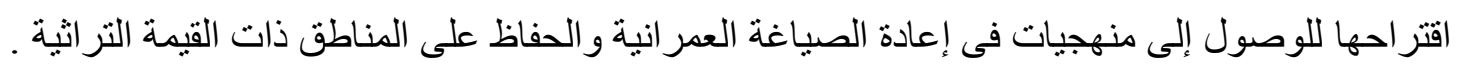
يمكن تلخيص المنهجيات المقترحة السابقة إلى النتائج التالية:

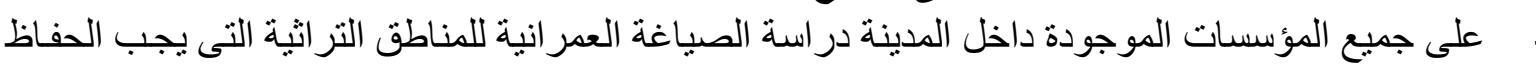

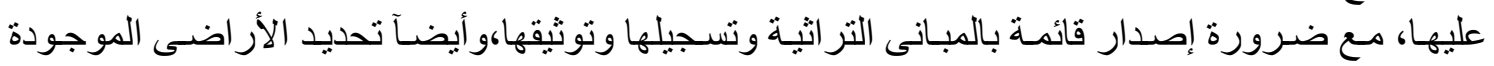
داخل الحيز العمر انى لتلك المناطق فئن. تطوير وتحسين شبكة الطرق و البنية التحتية لتأهيل مركز المدينة ،ونطوير الأماكن و الفر اغات.

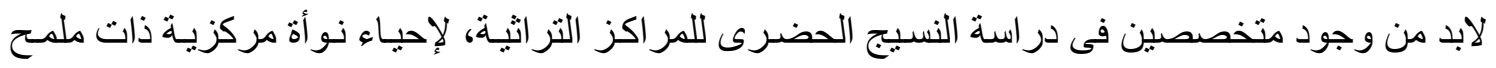
ظاهر بالمدينة. الاهتمام بالمبانى التر اثنية و الحفاظ عليها بطرق كثيرة كأحد العناصر الهامـة التى تعود بـالنفع على صياغة العمر ان في المناطق التر التئية

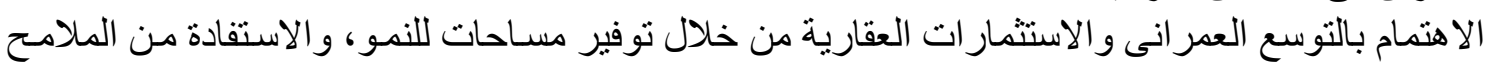
العمر انية للمناطق التراثية فى تللك الامتدادات العمر انية. 
لـابد من وضع أولويات فى عمليات الحفاظ على المنـاطق التراثيـة و الأهتمـام بها بالثكل المطلوب لتحقيق المقومات و التتمية السياحة و الاقتصادية.

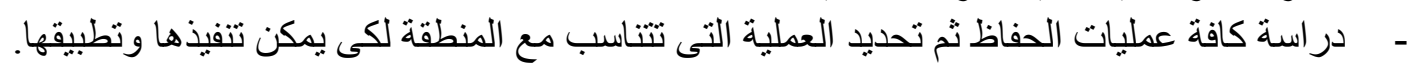

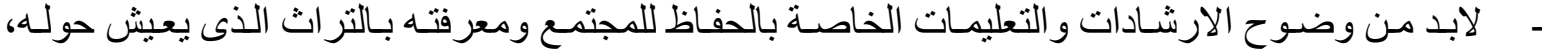

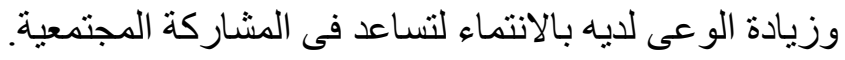

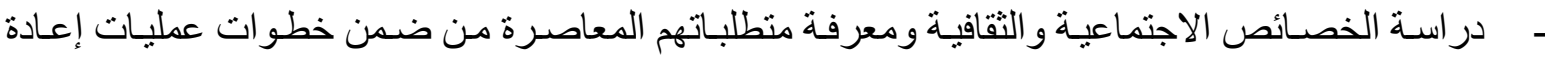

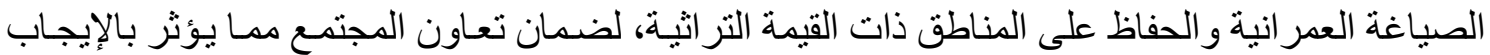
فى نجاح هذه العملية.

- لابد من التنسيق و الترابط بين الجوانب المجتمعية و المؤسسات التى تعمل فى مجال العمر ان بالمدينة.

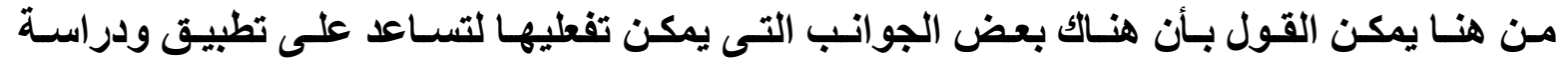

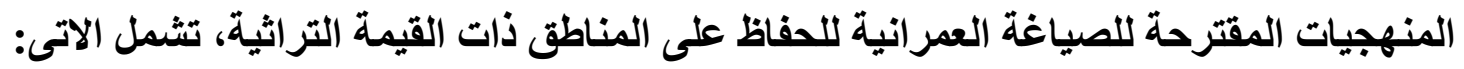

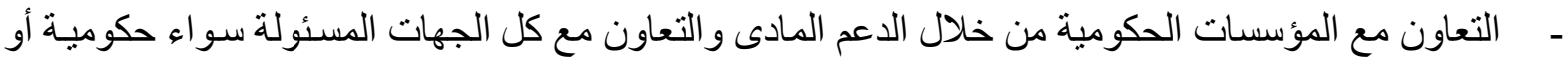
مستقلة.

- - ت - تدعيم النظم القانونية التى تساهم فى الحفاظ.

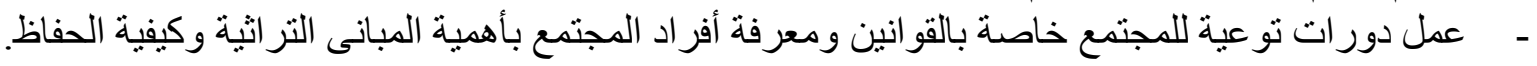
- دراسة التجارب دولية السابقة في مجال الحفاظ.

\begin{tabular}{|c|c|c|c|c|c|}
\hline التجارب & ل دور & الجاتب القانونى & المؤسسات & & \\
\hline & & $\bullet$ & - & الجاتب العمرانى ( الصياغة العمرانية) & -1 \\
\hline & & - & - & للجدينة التراثية) العمراني (الملامح العمرانية & -2 \\
\hline \multirow[t]{2}{*}{$\bullet$} & - & - & - & القيمة التراثية الحفاظ على المناطق ذات & -3 \\
\hline & & - & - & منهجيات التعامل مع المناطق ذات & -4 \\
\hline \multirow[t]{3}{*}{$\bullet$} & - & $\bullet$ & $\bullet$ & الجاتب الاجتماعى & -5 \\
\hline & - & & - & منهجية إعاد برامج ومشاريع & -6 \\
\hline & - & - & - & الجاتب القانونى & -7 \\
\hline
\end{tabular}

جدول توضح العلاقة بين المنهجيات المقترحة وجو انب التفعيل بالمدينة

- يمكن القول بأن المنهجيات الأكثر ارتباط بالجوانب التفعيل هى منهجيات الحفاظ على المناطق التراثية و الجانب المجتمعى . 
شكل يوضح العلاقة بين ارتباط المنهجيات المقترحة للصياغة و جوانب التفعيل المصدر: الباحث

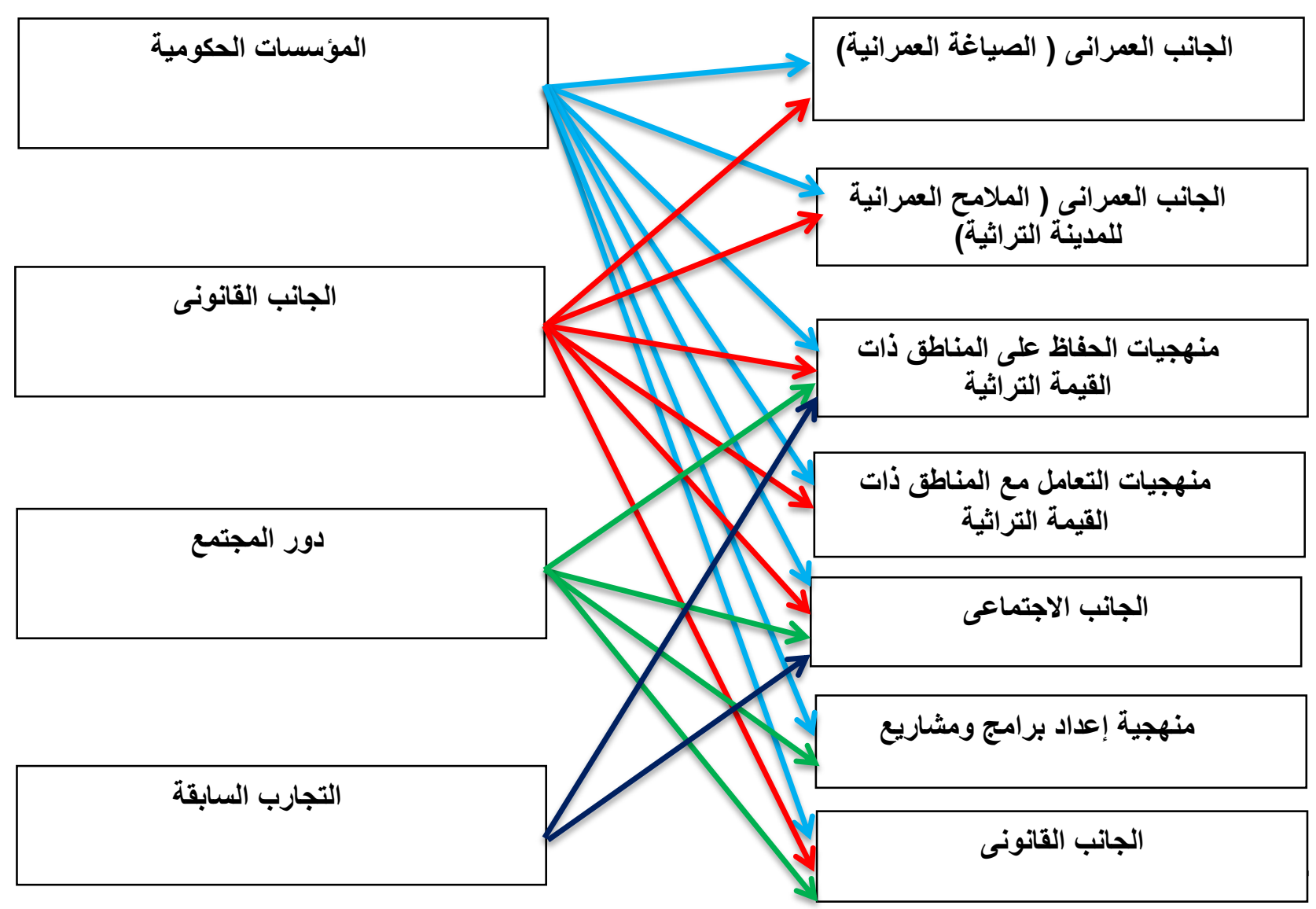

(1) Azza Hussein the Rehabilitation of deteriorated Areas ph d- 1989- p23

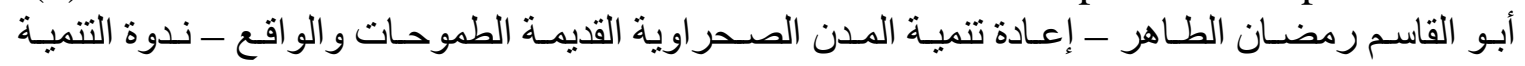

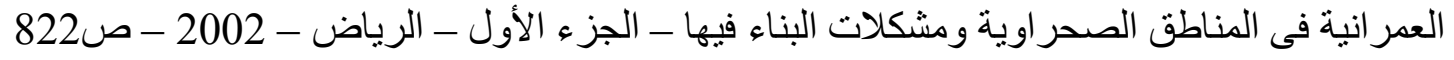

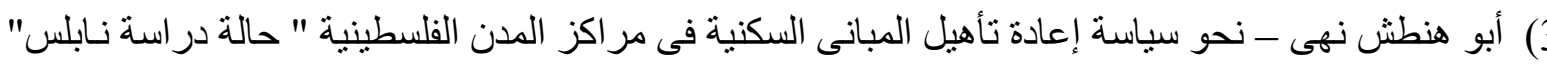

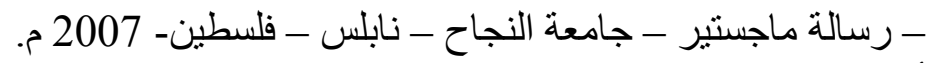

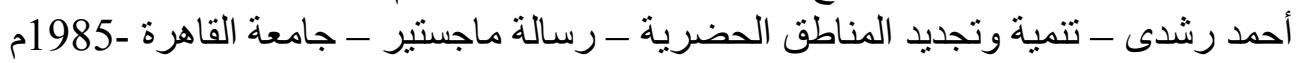

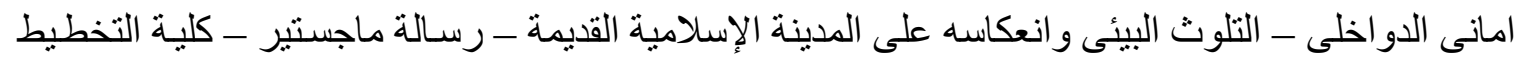

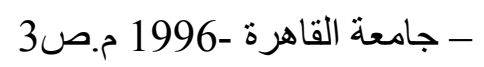

أيمن جمال الدين أحمد عبد التواب - الحفاظ والتطوير العمر انى - ماجستير - جامعة الاسكندرية - 1998م

ايهاب نصر الدين أحمد - الثـارع التجارى بين النظرية والتطبيق - ماجستير - جامعة حلو ان - 2000 - 
أسامة السيد أحمد - التجمعات العمر انية الجديدة حول مدينة القاهرة الكبرى - ماجستير - جامعة عين شمس

$$
.2003-
$$

المالكى قبيلة فارس - التراث العمر انى و المعمارى فى الوطن العربى ـ الحفاظ، الصيانة، إعـادة التأهيل ـ

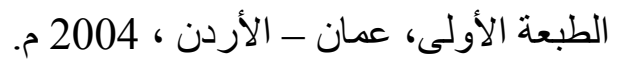

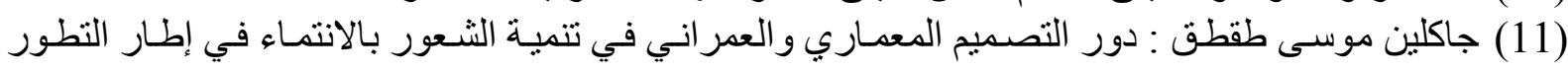

الثقافي للمجتمعات ، رسالة دكتور اه ، جامعة القاهرة ، كلية الهندسة ، قسم الهندسة المعمارية ، 2002.

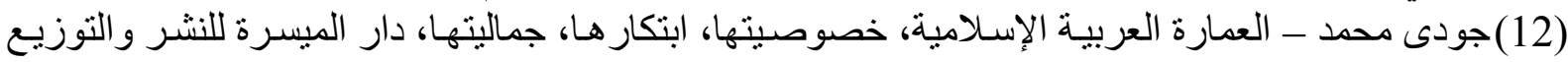

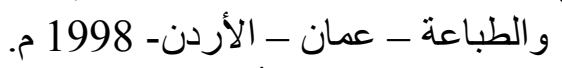

(13) حسن محمود حسن أحمد - إحياء المناطق التاريخية من خـلال إعادة توظيفها - ماجستير - كليـة التخطيط

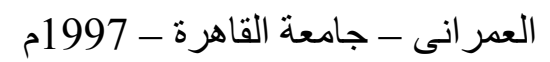

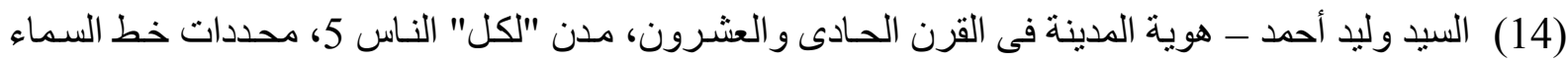

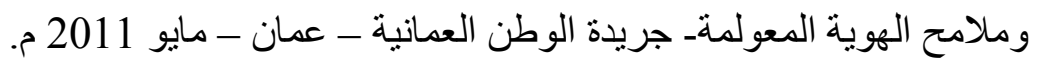

(15) صلاح قنصوه - نظرية القيمة فى الفكر المعاصر ـ كتاب ـ دار الثقافة للنشـر و التوزيع ـ القاهرة - 1987

$$
\text { م.ص12 (12) }
$$

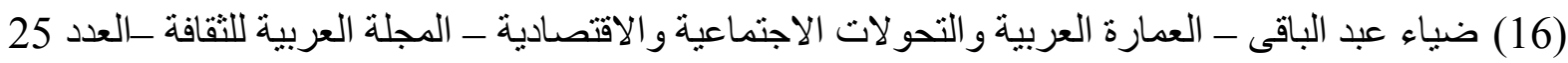

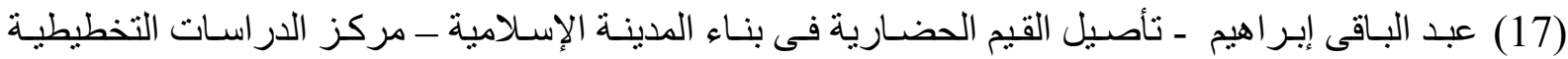

$$
\text { و المعمارية - القاهرة - 1982م الهم }
$$

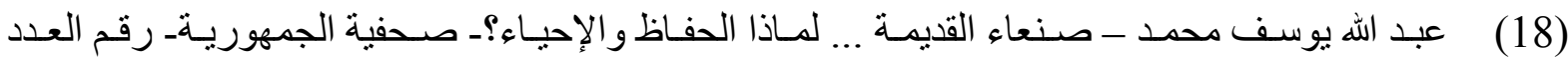

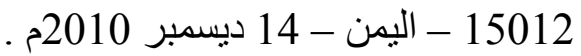

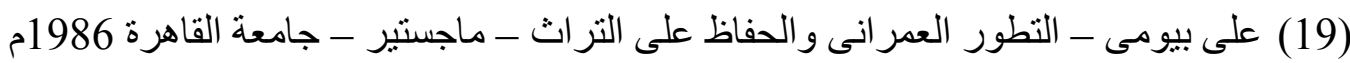

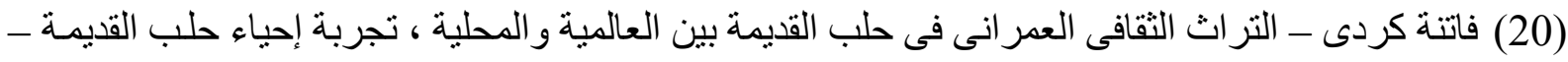

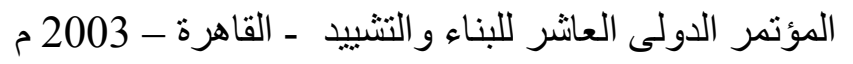

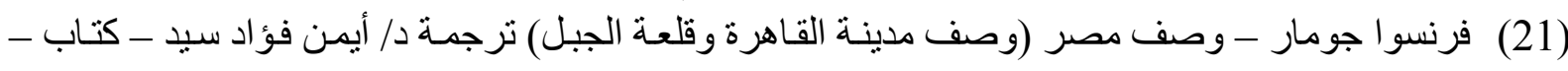

$$
\text { مكتبة الخانكى - الاهرة - } 1988 \text { - مدار }
$$

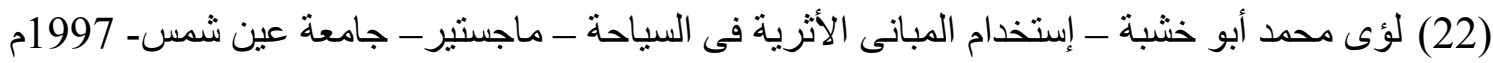

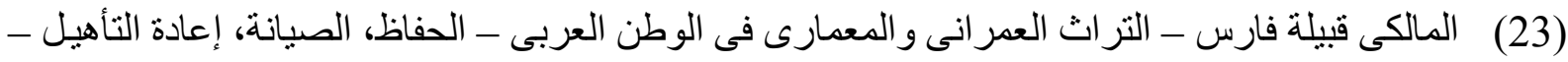

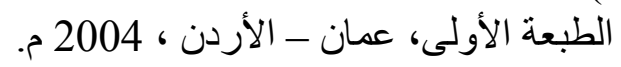

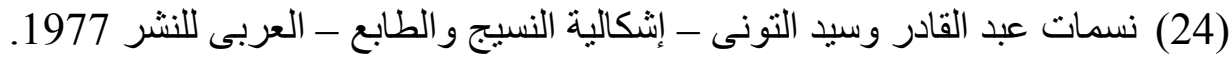

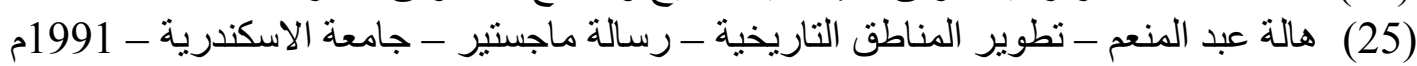

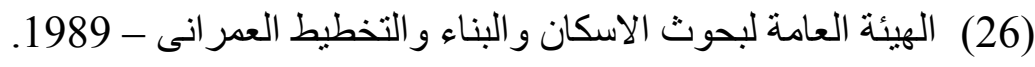

(27) يحيى وزيرى - العمارة الإسلامية والبيئة - سلسة عالم المعرفة اليطة - يونيو 2004 م. 